\title{
Multistage origin of dunite in the Purang ophiolite, southern Tibet, documented by composition, exsolution and $\mathrm{Li}$ isotope characteristics of constituent minerals
}

\author{
Fahui Xiong ${ }^{1,2}$, Jingsui Yang ${ }^{1}$, Hans-Peter Schertt ${ }^{3,2}$, Zhao Liu ${ }^{4}$, and Xiangzhen $\mathrm{Xu}^{1}$ \\ ${ }^{1}$ Center for Advanced Research on the Mantle (CARMA), Key Laboratory of Deep-Earth Dynamics of Ministry \\ of Natural Resources, Institute of Geology, Chinese Academy of Geological Sciences, Beijing 100037, China \\ ${ }^{2}$ Key Laboratory of Depositional Mineralization and Sedimentary Minerals, \\ Shandong University of Science and Technology, Qingdao 266590, China \\ ${ }^{3}$ Ruhr University Bochum, Faculty of Geosciences, Institute of Geology, \\ Mineralogy and Geophysics, 44780 Bochum, Germany \\ ${ }^{4}$ MNR Key Laboratory of Metallogeny and Mineral Assessment, \\ Institute of Mineral Resources, CAGS, Beijing 100037, China
}

Correspondence: Fahui Xiong (xiongfahui@126.com)

Received: 31 March 2019 - Accepted: 6 January 2020 - Published: 17 February 2020

\begin{abstract}
The Purang ophiolite, which crops out over an area of about $650 \mathrm{~km}^{2}$ in the western Yarlung-Zangbo suture zone, consists chiefly of mantle peridotite, pyroxenite and gabbro. The mantle peridotite is comprised mainly harzburgite and minor dunite. Locally, the latter contains small pods of chromitite. Pyroxenite and gabbro occur as veins of variable size within the peridotite; most of them strike northwest, parallel to the main structure of the ophiolite.

Three types of dunite occur in the Purang ophiolite: dunite that envelopes podiform chromitite (1) and lenses of dunite with either Cr-rich spinel (2) or Cr-poor spinel (3) in a harzburgite host. The constituent minerals of dunite envelopes around podiform chromitite are similar in composition to those of transition-zone dunite (Fo91.01-91.87 in olivine; $\mathrm{Cr} /(\mathrm{Cr}+\mathrm{Al})(\mathrm{Cr} \#)=41.5-47.0$ and $\mathrm{Mg} /\left(\mathrm{Mg}+\mathrm{Fe}^{2+}\right)(\mathrm{Mg} \#)=58.9-63.0$ in Cr-spinel $)$. Forsterite contents in olivine decrease from type 2 lenses with Cr-rich spinel (91.9-93.0) to type 1 dunite enveloping chromitite (91.7-93.7) to type 3 lenses with Cr-poor spinel (95.3-96.0). Similarly, Cr\# in spinel decreases from type 2 (66.9-67.9) to type 1 (41.5-47.0) to type 3 (19.8-20.6). In addition, $\mathrm{Al}_{2} \mathrm{O}_{3}$ in clinopyroxene is highest in type $2(3.48-5.24 \mathrm{wt} \%)$ and decreases to type $1(1.56-3.29 \mathrm{wt} \%)$ and type $3(0.78-0.86 \mathrm{wt} \%)$. Olivine in type 1 dunite enveloping podiform chromitite has $\mathrm{Li}$ concentrations and $\delta^{7} \mathrm{Li}$ values of $1.48-1.71 \mathrm{ppm}$ and $6.19 \% \%_{-}$ $7.98 \%$, respectively. Type 2 dunite lenses with $\mathrm{Cr}$-rich spinel contain olivine with $\mathrm{Li}=0.98-1.64 \mathrm{ppm}$ and $\delta^{7} \mathrm{Li}=6.77 \%$ - $10.99 \%$. The type 3 dunite lenses with Cr-poor spinel show the highest values of $\mathrm{Li}=0.94-$ $1.40 \mathrm{ppm}$ and $\delta^{7} \mathrm{Li}=10.25 \%$ o- $14.20 \%$. Exsolution lamellae of clinopyroxene and magnetite occur as oriented intergrowths in olivine of type 3 dunite lenses with Cr-poor spinel.

We suggest that the Purang ophiolite developed during two main stages of formation. In the first stage, abyssal peridotites formed in a mid-ocean-ridge environment. During the second stage, hydrous high-Mg boninitic melts were produced by high degrees of partial melting in a supra-subduction zone mantle wedge, which reacted with peridotite to form type 2 dunite pods with high-Cr\# spinel. At lower degrees of partial melting in the same mantle wedge, Al-rich melts were produced, which reacted with peridotite to form type 3 dunite pods that contain lowCr\# spinel. These Al-rich melts were also relatively rich in $\mathrm{Ti}^{4+}, \mathrm{Ca}^{2+}$ and $\mathrm{Fe}^{3+}$, which were incorporated into the olivine structure by appropriate substitutions. During cooling, these elements exsolved as lamellae of magnetite and clinopyroxene.
\end{abstract}




\section{Introduction}

The Li isotope system is of particular significance in distinguishing diverse sources of melt in subduction zones; it is also very sensitive to different types of dehydration reactions and metamorphic settings (Chen et al., 2000). The ${ }^{7} \mathrm{Li}$ can be preferentially released from the subducting plate, resulting in ${ }^{7} \mathrm{Li}$ isotope enrichment in the overlying mantle wedge and ${ }^{6} \mathrm{Li}$ isotope enrichment in the residue (Tomascak et al., 2002). Release from the slab to the mantle wedge causes changes in both the quantity and isotopic composition of Li. Although there is overlap, $\mathrm{Li}$ isotope compositions can also be of help in distinguishing different sources of formation. Eclogite and granulite, in particular, as well as altered mid-ocean-ridge basalt (MORB) and marine sediments, for instance, may show much lower values of ${ }^{7} \mathrm{Li}$ compared to ocean-island basalt (OIB), MORB or arc lava (Tomascak et al., 2002). However, $\mathrm{Li}$ isotope variations have been studied far less in residual mantle peridotite, although such information is essential for our understanding of partial melting processes in subduction zones (Su et al., 2016, 2017). Previous work has shown that $\mathrm{Li}$ isotope compositions can be used to trace the process of rock melting reactions (Su et al., 2015, 2017; Xiao et al., 2017). Such an approach is thus of particular interest for understanding the origin of the different types of dunite investigated in the current study. Based on the $\mathrm{Li}$ isotope results, we can expect important information for tracking and distinguishing various subduction-related processes and the interaction between melt and olivine to understand the extent of mantle heterogeneity in the Purang peridotite.

Different types of non-primary oxides such as magnetite, ilmenite and rutile that are commonly associated with silicate phases can occur in olivine as a result of different exsolution mechanisms (see also Otten, 1985; Banfield et al., 1990). Different Ti-, Cr- and Fe-bearing silicate exsolution lamellae have also been observed (e.g., Arai, 1978; Ashworth, 1979; Moseley, 1981; Drury and Van Roermund, 1988; Dobrzhinetskaya et al., 1996; Risold et al., 1997; Hacker et al., 1997). Spinel exsolution in olivine has also been reported in both terrestrial rocks and meteorites (Mikouchi et al., 2000). Most of these exsolution intergrowths have been described from minerals of plutonic rocks, such as in the fayalite of augite syenite (Markl et al., 2001), olivine of spinel-olivine cumulate (Ashworth and Chambers, 2000) and olivine of gabbro-wehrlite (Abzalov, 1998). Spinel exsolution has also been discovered in high-pressure (HP) and ultra-high-pressure (UHP) metamorphic rocks, such as magnetite in olivine of garnet peridotite (Zhang et al., 1999, 2004; Zhao et al., 2006; Song et al., 2004). In addition, other exsolved phases such as magnetite + clinopyroxene exsolution lamellae in olivine have also been reported from ophiolitic mantle peridotites (Xiong et al., 2017, 2019a; Liang et al., 2018).

In this contribution, we describe and present mineralogical and $\mathrm{Li}$ isotope data on three types of dunite associated with chromitite deposits of the Purang ophiolite in Tibet to interpret their formation.

\section{Geological setting}

The Purang massif (Fig. 1) is the largest ophiolite sequence in the western part of the Yarlung-Zangbo suture zone and consists mainly of a large mafic to ultramafic body extending for $\sim 600 \mathrm{~km}^{2}$ (Yang et al., 2011, Xiong et al., 2018). The ultramafic rocks include mainly harzburgite and minor lherzolite and dunite, all of which contain irregularly shaped and deformed bodies of chromitite (Xiong et al., 2018; Fig. 1b). The main fabric of the peridotites is directed northwestsoutheast. Individual dikes of pyroxenite, gabbronorite, dolerite and rare basalt locally crosscut in a northwesterly direction of the peridotitic mantle lithologies (Fig. 1b; Liu et al., 2015). The ophiolite tectonically overlies a late Cretaceous mélange along its southern boundary that includes some volcanic rocks and metamorphosed, shallow to bathypelagic carbonate rocks and shales of Triassic age (Xiong et al., 2013, Fig. 1). In the southwest, the ophiolite is bounded by a fault zone that contains rocks of a serpentinite mélange and is thrust over Triassic carbonaceous slates of the Tethyan Himalaya in the southeast (Fig. 1b).

Serpentinized peridotites of the Purang massif are directly overlain by hyaloclastite rocks and massive basaltic flows that are intercalated with green- and burgundycolored chert, siliceous limestone, and silty shale interbedded with thin sandstone layers (Liu et al., 2015). Radiolarian fossils recovered from these chert layers display Late Jurassic-Lower Cretaceous biostratigraphic ages (Xiong et al., 2013). Basaltic lavas in the Purang massif are $\sim 137 \mathrm{Ma}$ in age and show enriched mid-oceanridge basalt (E-MORB) and ocean-island basalt (OIB) geochemical affinities with relatively high contents of $\mathrm{TiO}_{2}$ (2.05 wt \%); low ratios of (La/Yb) ${ }_{N}$ (2.04 to 2.35); and high values of $\left({ }^{143} \mathrm{Nd} /{ }^{144} \mathrm{Nd}\right)_{t}=0.512777-0.512779, \varepsilon_{\mathrm{Nd}}(t)=$ $+6.1 \sim+6.2$, and $\left({ }^{86} \mathrm{Sr} /{ }^{87} \mathrm{Sr}\right)_{t}=0.70688-0.70710$ (Liu et al., 2015).

$\mathrm{U}-\mathrm{Pb}$ laser ablation, multi-collector, inductively coupled plasma mass spectrometry (LA-ICP-MS) dating of zircon crystals recovered from the dolerite and gabbro dikes within the peridotites has yielded crystallization ages ranging from 140 to $120 \mathrm{Ma}$ (Miller et al., 2003; Li et al., 2008; Liu et al., 2011; Chan et al., 2015; Xiong et al., 2019b; Meng et al., 2016, 2019; Zheng et al., 2019). Thus, the magmatic age of the Purang massif is considered to be Early Cretaceous. Major geotectonic sources of the Purang ophiolite are connected with a detachment fault at a slow-spreading ridge (Liu 


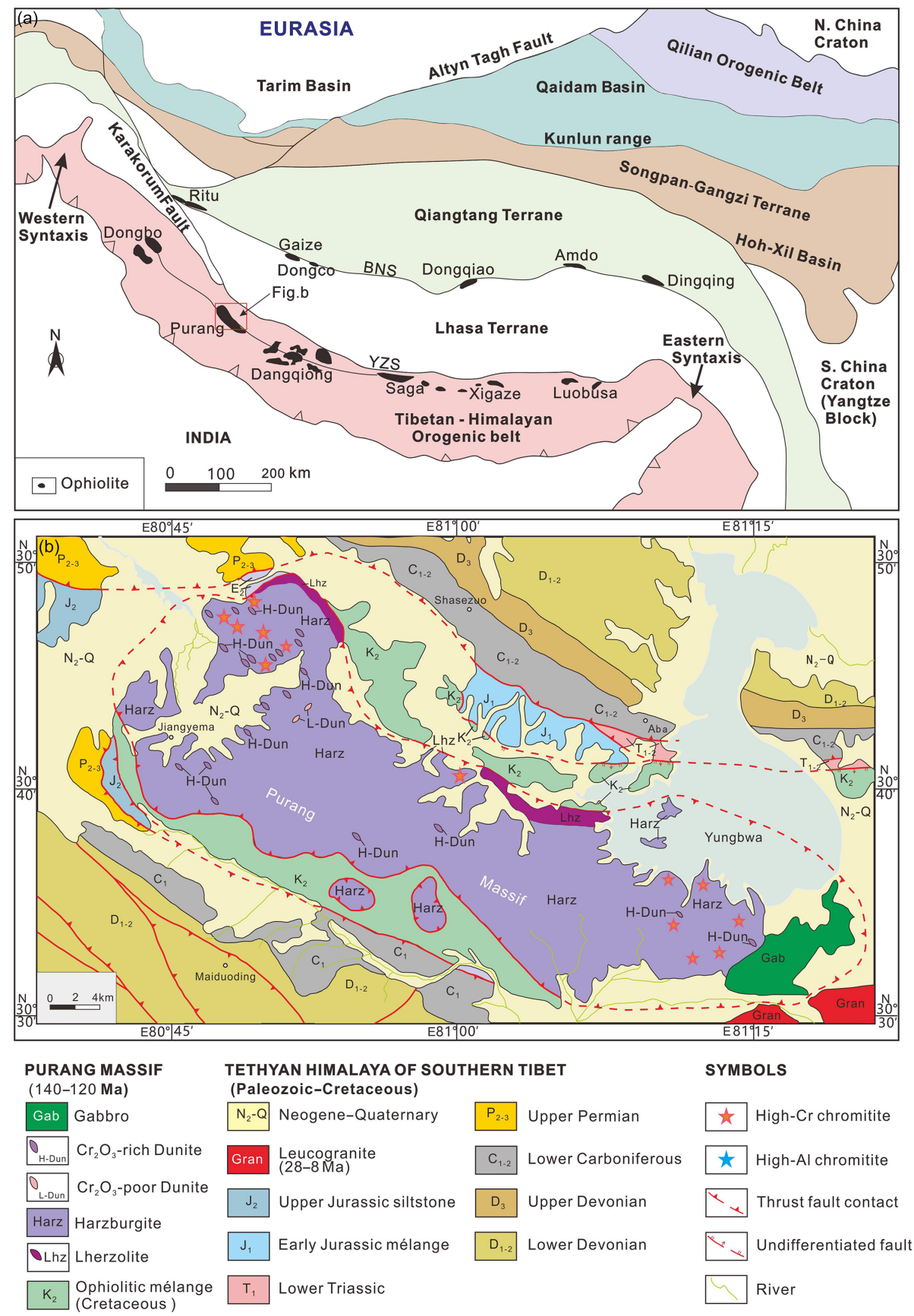

Figure 1. (a) Simplified tectonic map of the Tibetan Plateau, composed of several terranes and separated by well-defined suture zones. The (Indus-)Yarlung-Zangbo suture zone is the southernmost of these sutures, separating the Lhasa block to the north from the Indian plate to the south. Abbreviations: BNS, Bangong-Nujiang suture; IYZS, Indus-Yarlung-Zangbo suture. Locations of other UHP-mineral-bearing ophiolites along the YZSZ follow Xiong et al. (2019a). (b) Detailed geological map of the study area indicated in (a) (modified from Xiong et al., 2013; Dai et al., 2013; Liu et al., 2014).

et al., 2014), providing a continental-margin ophiolite influenced by plume-type magmatism (Liu et al., 2015), recycled subcontinental lithospheric mantle (Gong et al., 2016) and a sub-oceanic lithospheric mantle wedge from an underlying downgoing slab (Li et al., 2015; Su et al., 2015).

\section{Sampling and analytical methods}

Our regional-scale geological fieldwork on the Purang ophiolite focused on the different rock types of the massif. Harzburgite and three types of dunite could be distinguished based on their contrasting appearance in the field (Fig. 2) 


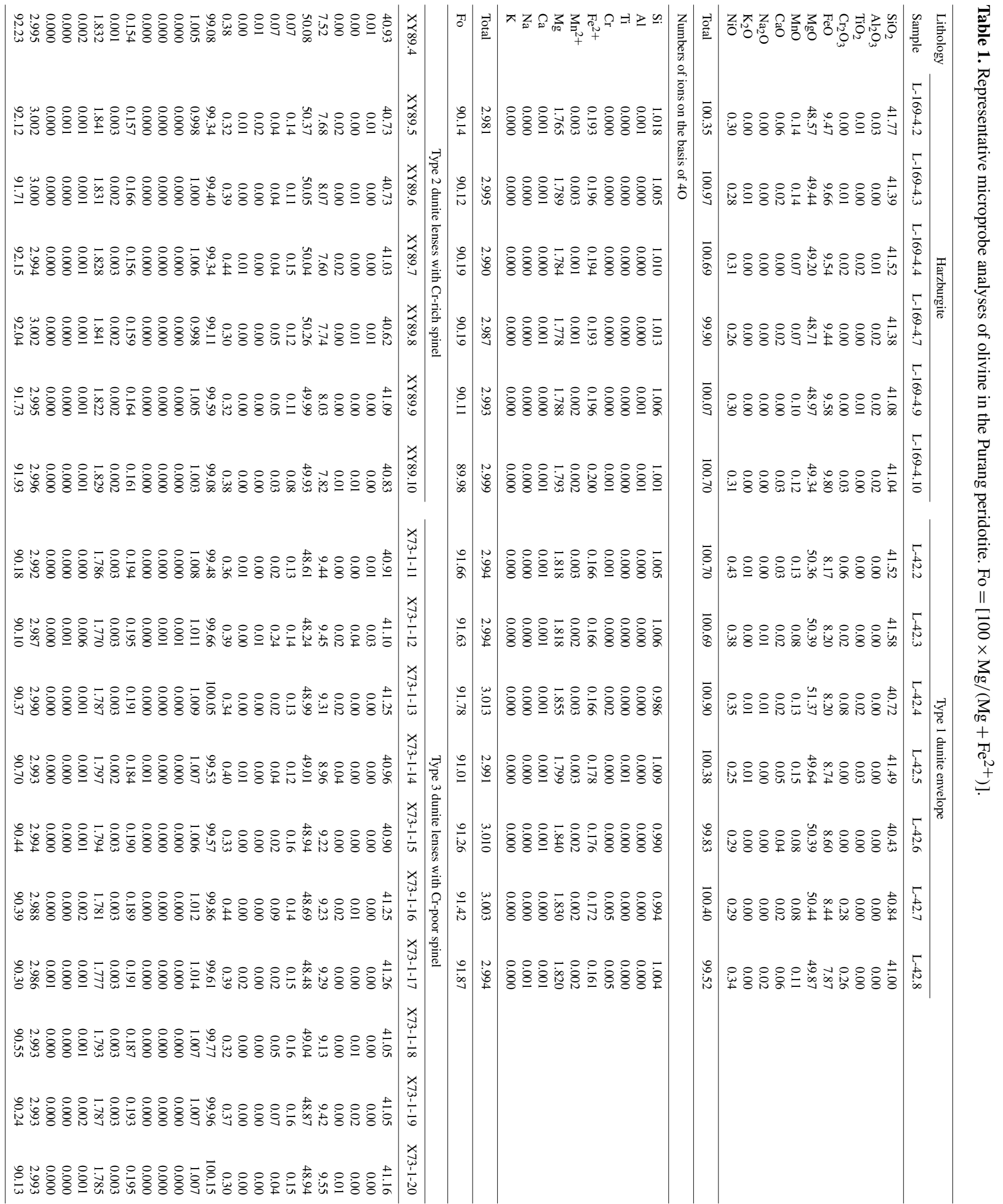


and modal proportions of the major minerals estimated from thin sections. Most dunite in the Purang massif occurs as lenses in the harzburgite with $\mathrm{Cr}$-rich spinel. Less abundant are lenses with $\mathrm{Cr}$-poor spinel and dunite envelopes around chromitite bodies. The dunite with $\mathrm{Cr}$-poor spinel is found only in the northwestern part of the massif (at $30^{\circ} 39.647^{\prime} \mathrm{N}$, $80^{\circ} 47.888^{\prime} \mathrm{E}$; see Fig. 1b). The dunite lenses with Cr-rich spinel are randomly distributed over the entire massif, while the dunite forming envelopes around chromitite occurs both in the northwestern and southeastern parts of the massif (Fig. 1b).

The microtextural characteristics of the Purang peridotite were studied with the backscattered electron (BSE) technique using an FEI Nova Versa-3D scanning electron microscope (SEM) equipped with an energy-dispersive spectrometer (EDS) at the Key Laboratory of Deep-Earth Dynamics of the Ministry of Natural Resources, Institute of Geology, Chinese Academy of Geological Sciences. The operating conditions for the SEM were $20 \mathrm{kV}$ excitation voltage and $15 \mathrm{nA}$ beam current (Co metal used for calibration). Olivine, pyroxene and Cr-spinel were analyzed with a JEOL JXA-8100 electron microprobe (EMP) at the Key Laboratory of DeepEarth Dynamics of Ministry of Natural Resources, Institute of Geology, Chinese Academy of Geological Sciences. All analyses were carried out in the wavelength-dispersive Xray spectroscopy (WDS) mode. Analytical conditions were $15 \mathrm{kV}$ accelerating voltage, $20 \mathrm{nA}$ beam current, and $2 \mu \mathrm{m}$ spot diameter with a counting time of $20 \mathrm{~s}$ on the peaks and $10 \mathrm{~s}$ on the background.

Transmission electron microscopy (TEM) was used to determine the composition and symmetry of the mineral inclusions in olivine; sample preparation was performed using the focused ion beam (FIB) technology from MNR Key Laboratory of Metallogeny and Mineral Assessment, Institute of Mineral Resources, Chinese Academy of Geological Sciences. Typical TEM foils prepared had the dimensions $15 \mu \mathrm{m} \times 10 \mu \mathrm{m} \times 0.20 \mu \mathrm{m}$. A FIB single beam device (FEI Versa 3D) operated at CAGS was used for sample preparation. A Ga ion beam ( $30 \mathrm{keV}$ acceleration voltage) focused onto a selected location of the sample surface was used to sputter material from the sample. For details of the TEM method used here, see Wirth et al. (2009).

The in situ $\mathrm{Li}$ isotope measurement on olivine was performed using a Cameca IMS-1280 Secondary ion mass spectrometry (SIMS) from the Key Laboratory of Mineral Resources, Institute of Geology and Geophysics, Chinese Academy of Sciences. The primary $\mathrm{O}$ ion beam accelerated at $13 \mathrm{kV}$ with an intensity of about 15 to $30 \mathrm{nA}$. The beam spot was elliptical, with a size of about $20 \mu \mathrm{m} \times 30 \mu \mathrm{m}$. Positive secondary ions were measured on the ion multiplier in pulse-counting mode with a mass resolution (M/DM) of 1500 and an energy slit opening of $40 \mathrm{eV}$ without any energy offset. A total of $180 \mathrm{~s}$ of pre-sputter without grating was applied prior to analysis. The secondary ion beam position in the contrast aperture and the magnetic field and en- ergy offset were automatically centered prior to each measurement. The measurement was carried out for 30 cycles, with a counting time of 12,2 , and $4 \mathrm{~s}$ for ${ }^{6} \mathrm{Li}$, a background sample of 6.5 mass, and ${ }^{7} \mathrm{Li}$, respectively. Using an olivine sample 09XDTC1-24OL with a forsterite component of 94.2 as standard ( $\mathrm{Su}$ et al., 2016), the similar composition of the standard as compared to the analyzed olivine eliminates any possible contribution of the matrix to the data obtained (Su et al., 2016). The measured $\delta^{7} \mathrm{Li}$ values are given as $\delta^{7} \mathrm{Li}\left(\left[\left({ }^{7} \mathrm{Li} /{ }^{6} \mathrm{Li}\right)_{\text {sample }} /\left({ }^{7} \mathrm{Li} /{ }^{6} \mathrm{Li}\right)_{\mathrm{L}-\mathrm{SVEC}}-\right.\right.$ $1] \times 1000)$, relative to units of the standard National Institute of Standard and Technology (NIST) SRM 8545 (LSVEC). The instrumental mass fractionation is expressed as $\delta^{7} \mathrm{Li}=\delta^{7} \mathrm{Li}_{\text {SIMS }}-\delta^{7} \mathrm{Li}_{\text {MC-ICPMS }}$. A total of 22 analyses of the standard confirmed a homogeneous Li isotopic composition of $\Delta i=26.0 \pm 1.9 \%$ (2SD) (Su et al., 2015). The external $2 \sigma$ errors of the isotope compositions for both standard and sample are less than $2.5 \%$.

\section{Petrography}

\subsection{Harzburgite}

Most of the harzburgites from the Purang ophiolite are massive and show brownish colors (Fig. 2a). A few of them are serpentinized, whereby the alteration increases towards the chromitite inclusions. In general, they are coarse-grained and contain high amounts of olivine (80 vol \%-90 vol \%), about $10 \mathrm{vol} \%-20 \mathrm{vol} \%$ orthopyroxene, minor amounts of clinopyroxene $(<5 \mathrm{vol} \%)$ and accessory amounts of $\mathrm{Cr}$ spinel (Figs. 2, 3a). They show a characteristic porphyroblast texture with large olivine and orthopyroxene crystals (1-5 and 5-20 mm, respectively), which display strongly embayed grain boundaries filled with fine-grained olivine and pyroxene neoblasts $(\leq 100-200 \mu \mathrm{m})$. Olivine and orthopyroxene porphyroclasts show ductile deformation, such as undulatory extinction, kink bands and tectonic twinning.

\subsection{Type 1 dunite envelopes around chromitite}

Most of the podiform chromitites in the Purang ophiolite are surrounded by dunite envelopes that vary from a few centimeters to several meters in thickness (Fig. 2b). The thickest and best-developed ones occur around disseminated chromitite. This type of dunite is moderately fresh, light yellowish-brown in color and massive. Typical samples consist of 98 vol \% olivine and $2 \%$ magnesiochromite (Fig. 3b); neither clinopyroxene nor orthopyroxene has been identified in these rocks, not even as inclusions in olivine or chromite. Most olivine grains are subhedral, form granular crystals, and show grain sizes between 2 and $6 \mathrm{~mm}$. They rarely exhibit deformation structures such as kink banding or undulatory extinction. Spinel occurs as small euhedral to subhedral grains (Fig. 3b) and as larger (up to $5 \mathrm{~mm}$ ), irregular, 

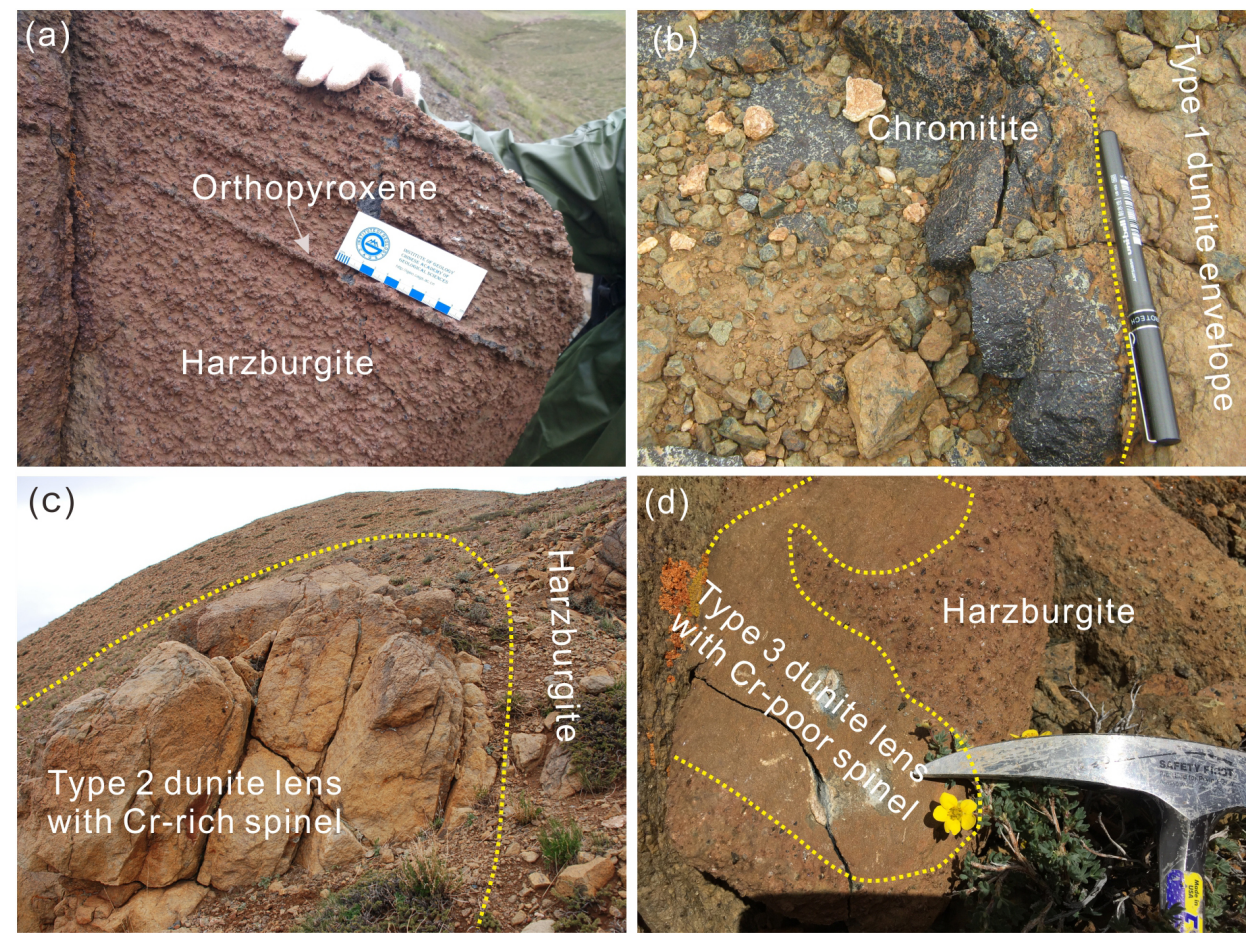

Figure 2. Field photographs showing the various lithologies in the Purang ophiolite: (a) harzburgite with fresh orthopyroxene, (b) massive chromitite with dunite envelope, (c) dunite with Cr-rich spinel in harzburgite, (d) dunite with Cr-poor spinel in harzburgite.

amoeboid crystals, some of which contain small inclusions of euhedral olivine.

\subsection{Type 2 dunite lenses with Cr-rich spinel}

This type of dunite lens is enclosed in harzburgite, forming very fresh and mainly brown rock inclusions (Fig. 2c). In general, the lenses are oriented northwest-southeast and show a width of $1-5 \mathrm{~m}$ and a length of $5-10 \mathrm{~m}$. The rock is mainly composed of olivine (95-99 modal\%, Fig. 3) and contains small amounts of Cr-rich spinel, orthopyroxene and clinopyroxene. The olivine is large in grain size, mainly $0.5-$ $3 \mathrm{~mm}$ in length. This type of olivine does not contain any inclusions or exsolution textures. Locally, the rims of olivine are replaced by serpentine. Chromian spinel has a particle size of between 0.2 and $1 \mathrm{~mm}$.

\subsection{Type 3 dunite lenses with $\mathrm{Cr}$-poor spinel}

Type 3 dunite lenses and pods in the Purang peridotites are mostly $0.1-2 \mathrm{~m}$ in width and commonly aligned in a northwest-southeast direction, roughly parallel to the main foliation of the host harzburgites (Fig. 2d). The dunite is fresh and nearly unaltered ( $<2$ vol \% serpentine) with brownishblack to yellowish-brown colors. It consists mainly of olivine (95-99 modal \%) and orthopyroxene $(2 \%-4 \%)$ with minor amounts of clinopyroxene and Cr-poor spinel. Olivine grains are commonly $2.5-3 \mathrm{~mm}$ in diameter, but recrystal- lized grains are much smaller. Some of the largest grains show undulatory extinction and deformation twinning. $\mathrm{Cr}-$ poor spinel, $0.2-1 \mathrm{~mm}$ in size, is mostly randomly distributed in the rocks but can locally concentrate to form small, disseminated clusters.

\section{Magnetite and diopside exsolution lamellae in olivine}

Magnetite and diopside exsolution lamellae were observed in thin sections of type 3 dunite lenses with Cr-poor spinel and confirmed by electron microprobe (EMP), SEM and TEM analysis. These lamellae (Figs. 3d, 4-6) can be oriented in different planes of the olivine structure (see below). Magnetite lamellae are generally 1-4 $\mu \mathrm{m}$ wide and show a length of 5-50 $\mu \mathrm{m}$. Diopside lamellae have the same width but are typically a little shorter (maximum length $30 \mu \mathrm{m}$ ). The two minerals are commonly intergrown, as shown in Fig. 5, where a single exsolution lamella is composed of magnetite (lower part) and diopside (upper part). Volumetrically, diopside exsolution lamellae are much less abundant than magnetite lamellae.

Because they are very small and commonly superimposed, it is difficult to obtain precise compositions. However, microprobe analyses show that exsolution lamellae of diopside have compositions that are nearly identical to irregularly distributed inclusions of diopside in olivine grains (Table 4). Some relatively large diopside inclusions appear to 


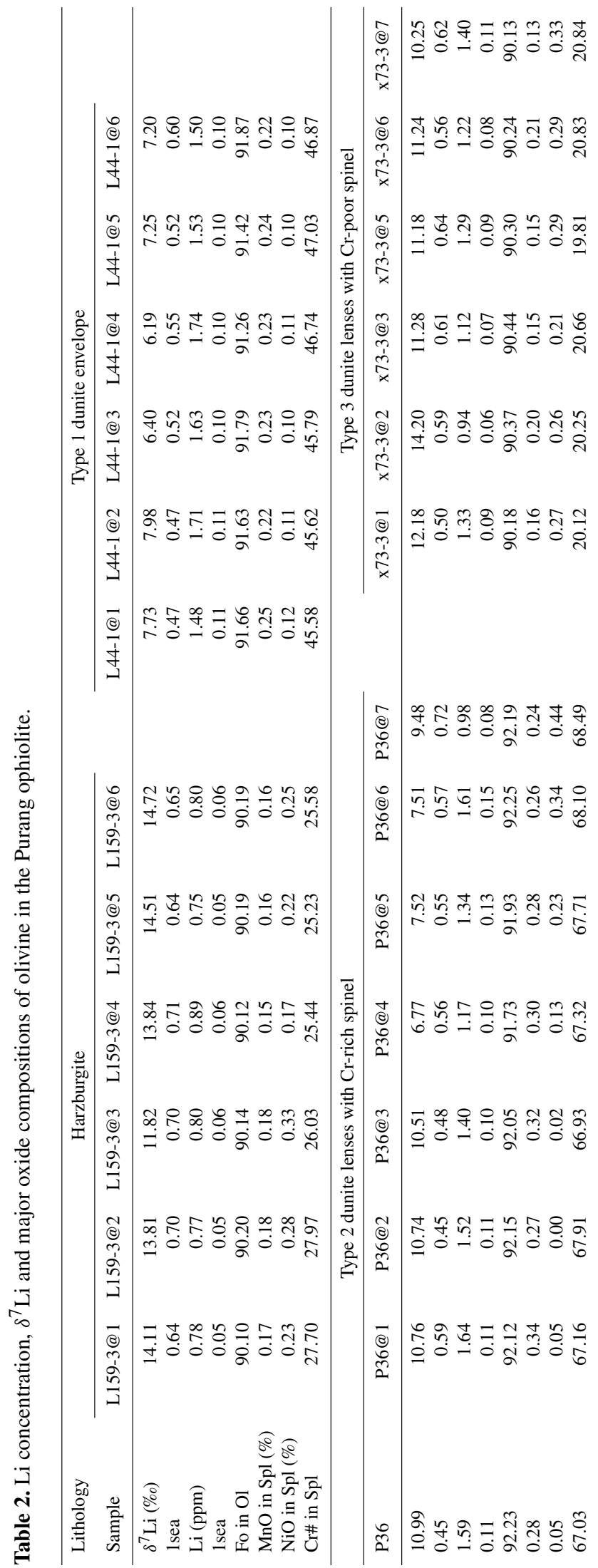

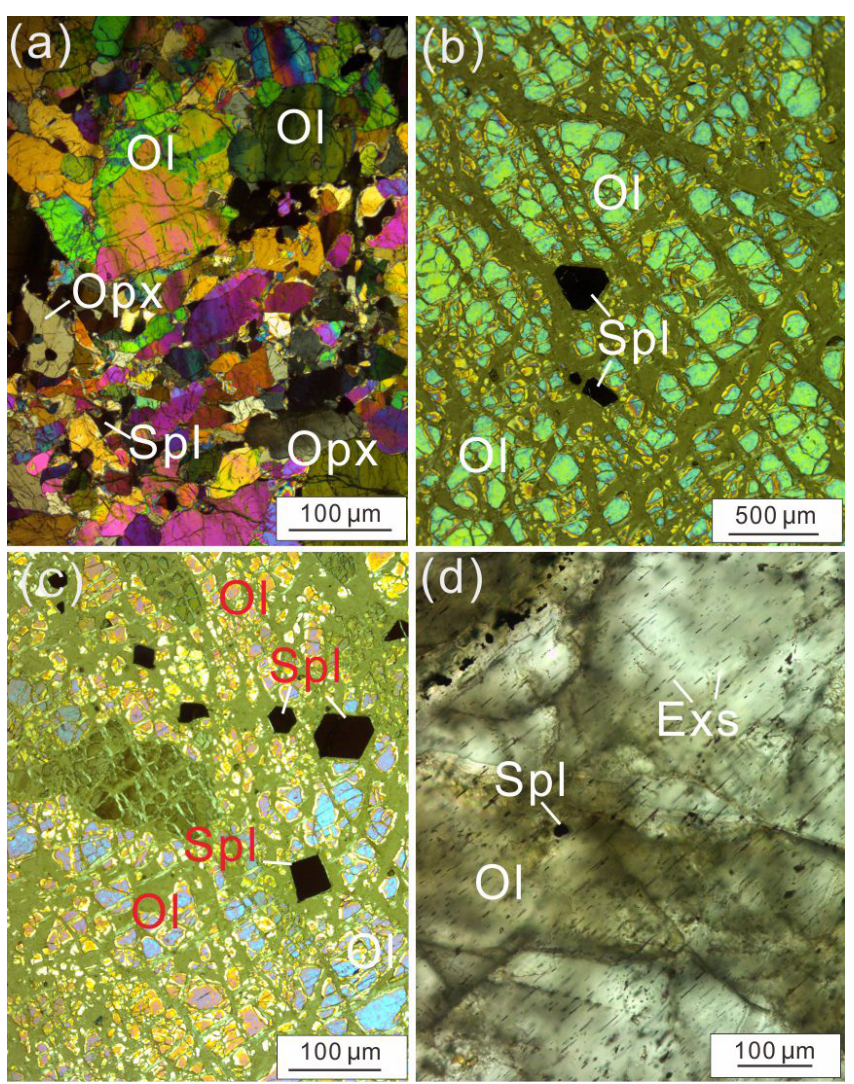

Figure 3. Photomicrographs of peridotite of the Purang ophiolite: (a) harzburgite showing the major minerals orthopyroxene and olivine with accessory chromian spinel, (b) dunite with fresh olivine and chromian spinels, (c) cumulate structure of olivine in type 2 dunite lens with $\mathrm{Cr}$-rich spinel, (d) fine-grained olivine from type 3 dunite with exsolution textures. Abbreviations: Ol, olivine; $\mathrm{Cpx}$, clinopyroxene; Opx, orthopyroxene; Spl, chromian spinel; Exs, exsolution lamellae.

have grown contemporaneously with the magnetite exsolution lamellae. Figure 4 also shows elemental X-ray maps of olivine grains with exsolved diopside and magnetite.

Using FIB technology, one TEM foil of a polymineralic exsolution lamella in olivine (Fig. 5a) was prepared; TEM and EDS analyses have proven the coexistence of diopside and magnetite (Fig. 5b, c, d). Likewise, HREM images and respective FFT (fast Fourier transform) diffraction patterns revealed that the exsolution lamellae mainly consist of diopside and magnetite (Fig. 6). The diopside and magnetite exsolution lamellae are mainly distributed along the (100) plane of olivine but also occur along the (013) and (010) planes. The relationship between the host olivine and the exsolution lamellae is $(100) \mathrm{Ol} / /(111) \mathrm{Mag} / /(100) \mathrm{Cpx},[001] \mathrm{Ol} / /[011]$ $\mathrm{Mag} / /[010]{ }_{\mathrm{Cpx}}$ (see also Moseley, 1984; Mikouchi et al., 2000; Markl et al., 2001; Ren et al., 2008; Xiong et al., 2017; Liang et al., 2018).

In addition to the diopside and magnetite exsolution lamellae in olivine described above, there are some very small, 


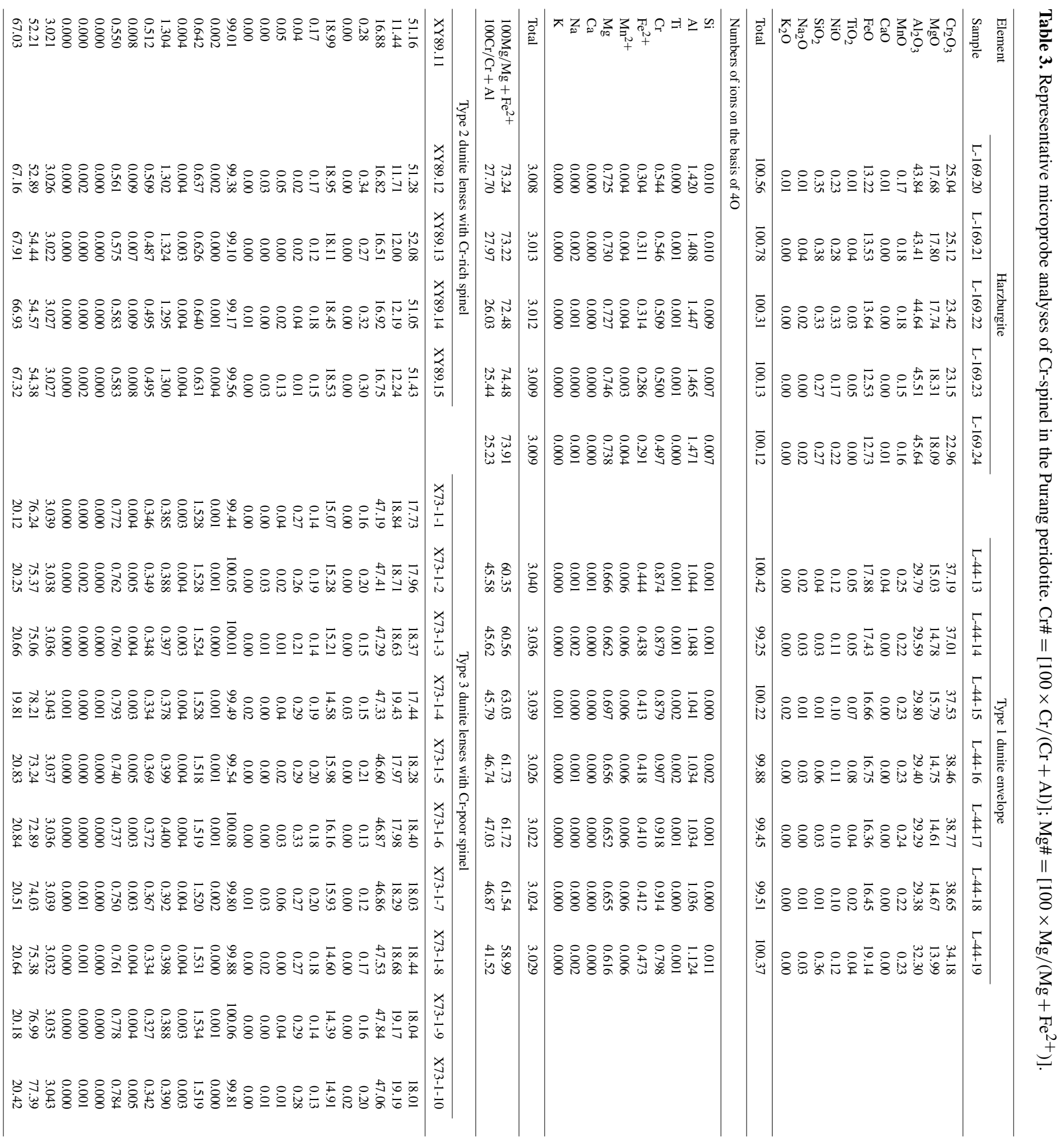


Table 4. Clinopyroxene compositions in different dunites and harzburgite of the Purang ophiolite.

\begin{tabular}{|c|c|c|c|c|c|c|c|c|c|c|c|}
\hline \multirow{2}{*}{$\begin{array}{l}\text { Lithology } \\
\text { Sample }\end{array}$} & \multicolumn{5}{|c|}{ Harzburgite } & & \multicolumn{5}{|c|}{ Type 1 dunite envelope } \\
\hline & L-169-1 & L-169-2 & L-169-3 & L-169-4 & L-169-5 & & L-43-3 & L-43-4 & L-43-5 & L-43-6 & L-43-7 \\
\hline $\mathrm{SiO}_{2}$ & 51.88 & 53 & 52.3 & 52.52 & 52.65 & & 52.53 & 51.99 & 53.25 & 52.75 & 52.28 \\
\hline $\mathrm{TiO}_{2}$ & 0.23 & 0.16 & 0.25 & 0.25 & 0.21 & & 0.07 & 0.08 & 0.06 & 0.05 & 0.07 \\
\hline $\mathrm{Al}_{2} \mathrm{O}_{3}$ & 5.45 & 5.13 & 4.61 & 4.41 & 4.28 & & 2.71 & 3.29 & 1.56 & 2.63 & 3.04 \\
\hline $\mathrm{Cr}_{2} \mathrm{O}_{3}$ & 1.32 & 1.14 & 1.25 & 1.13 & 0.91 & & 0.66 & 0.98 & 0.39 & 0.56 & 0.86 \\
\hline $\mathrm{FeO}$ & 2.01 & 3.87 & 2.4 & 2.2 & 2.33 & & 2.88 & 2.56 & 2.08 & 2.62 & 2.13 \\
\hline $\mathrm{NiO}$ & 0.05 & 0.06 & 0.04 & 0.04 & 0.05 & & 0.06 & 0.02 & 0.03 & 0.05 & 0.03 \\
\hline $\mathrm{MnO}$ & 0.07 & 0.11 & 0.07 & 0.09 & 0.08 & & 0.07 & 0.09 & 0 & 0.07 & 0.09 \\
\hline $\mathrm{MgO}$ & 14.77 & 20.88 & 15.67 & 15.77 & 15.75 & & 17.6 & 16.51 & 17.11 & 16.6 & 16 \\
\hline $\mathrm{CaO}$ & 21.83 & 14.58 & 21.73 & 22.11 & 21.75 & & 23.23 & 24.82 & 25.26 & 24.61 & 24.16 \\
\hline $\mathrm{Na}_{2} \mathrm{O}$ & 0.9 & 0.55 & 0.63 & 0.78 & 0.68 & & 0.07 & 0.07 & 0.03 & 0.08 & 0.05 \\
\hline $\mathrm{K}_{2} \mathrm{O}$ & 0 & 0 & 0.01 & 0 & 0 & & 0 & 0 & 0 & 0 & 0.01 \\
\hline Total & 98.50 & 99.50 & 99.00 & 99.30 & 98.70 & & 99.90 & 100.40 & 99.80 & 100.00 & 98.70 \\
\hline \multicolumn{12}{|c|}{ Numbers of ions on the basis of 60} \\
\hline $\mathrm{Si}$ & 1.906 & 1.901 & 1.914 & 1.917 & 1.929 & & 1.917 & 1.895 & 1.946 & 1.926 & 1.928 \\
\hline (4) $\mathrm{Al}$ & 0.094 & 0.099 & 0.086 & 0.083 & 0.071 & & 0.083 & 0.105 & 0.054 & 0.074 & 0.072 \\
\hline${ }^{(6)} \mathrm{Al}$ & 0.142 & 0.118 & 0.113 & 0.106 & 0.114 & & 0.034 & 0.037 & 0.014 & 0.039 & 0.060 \\
\hline $\mathrm{Ti}$ & 0.006 & 0.004 & 0.007 & 0.007 & 0.006 & & 0.002 & 0.002 & 0.002 & 0.001 & 0.002 \\
\hline $\mathrm{Cr}$ & 0.038 & 0.032 & 0.036 & 0.033 & 0.026 & & 0.019 & 0.028 & 0.011 & 0.016 & 0.025 \\
\hline $\mathrm{Fe}^{2+}$ & 0.062 & 0.116 & 0.073 & 0.067 & 0.071 & & 0.088 & 0.078 & 0.064 & 0.080 & 0.066 \\
\hline $\mathrm{Mn}^{2+}$ & 0.002 & 0.003 & 0.002 & 0.003 & 0.002 & & 0.002 & 0.003 & 0.000 & 0.002 & 0.003 \\
\hline $\mathrm{Mg}$ & 0.809 & 1.117 & 0.855 & 0.858 & 0.860 & & 0.958 & 0.897 & 0.932 & 0.904 & 0.880 \\
\hline $\mathrm{Ca}$ & 0.859 & 0.560 & 0.852 & 0.864 & 0.854 & & 0.908 & 0.970 & 0.989 & 0.963 & 0.955 \\
\hline $\mathrm{Na}$ & 0.064 & 0.038 & 0.045 & 0.055 & 0.048 & & 0.005 & 0.005 & 0.002 & 0.006 & 0.004 \\
\hline $\mathrm{K}$ & 0.000 & 0.000 & 0.000 & 0.000 & 0.000 & & 0.000 & 0.000 & 0.000 & 0.000 & 0.000 \\
\hline Total & 3.983 & 3.989 & 3.984 & 3.993 & 3.983 & & 4.016 & 4.020 & 4.014 & 4.011 & 3.994 \\
\hline En & 49.6 & 31.2 & 47.8 & 48.2 & 47.8 & & 46.3 & 49.7 & 49.8 & 49.3 & 50.1 \\
\hline Fs & 3.7 & 6.6 & 4.2 & 3.9 & 4.1 & & 4.6 & 4.1 & 3.2 & 4.2 & 3.6 \\
\hline Wo & 46.7 & 62.2 & 48 & 47.9 & 48.1 & & 48.9 & 46 & 46.9 & 46.2 & 46.2 \\
\hline Mg\# & 93 & 90.7 & 92.1 & 92.8 & 92.4 & & 91.7 & 92.1 & 93.7 & 91.9 & 93.1 \\
\hline \multicolumn{5}{|c|}{ Type 2 dunite lenses with Cr-rich spinel } & & \multicolumn{5}{|c|}{ Type 3 dunite lenses with Cr-poor spinel } & \\
\hline$X-74-2-5$ & $X-74-2-10$ & $X-74-2-11$ & $X-74-2-14$ & $X-74-2-15$ & & $\mathrm{X}-89-6$ & X-89-7 & X-89-8 & X-89-9 & $\mathrm{X}-89-10$ & \\
\hline 49.7 & 50.85 & 51.54 & 50.36 & 50.82 & & 54.91 & 55.55 & 55.51 & 54.94 & 54.7 & \\
\hline 0.12 & 0.19 & 0.15 & 0.12 & 0.14 & & 0.06 & 0.05 & 0 & 0 & 0.05 & \\
\hline 5.24 & 3.71 & 5.16 & 5.07 & 3.48 & & 0.79 & 0.78 & 0.81 & 0.79 & 0.86 & \\
\hline 0.69 & 0.48 & 0.73 & 0.8 & 0.9 & & 0.79 & 0.86 & 0.76 & 0.75 & 0.68 & \\
\hline 2.35 & 2.13 & 2.1 & 2.28 & 2.16 & & 1.58 & 1.42 & 1.56 & 1.61 & 1.29 & \\
\hline 0.01 & 0.03 & 0.1 & 0.04 & 0.04 & & 0.07 & 0 & 0.02 & 0.03 & 0.03 & \\
\hline 0.06 & 0.06 & 0.1 & 0.04 & 0.03 & & 0.07 & 0.03 & 0.08 & 0.05 & 0.07 & \\
\hline 15.03 & 15.94 & 15.58 & 15.49 & 15.94 & & 17.95 & 17.74 & 17.83 & 17.92 & 17.18 & \\
\hline 26.28 & 26 & 24.32 & 25.77 & 26.33 & & 23.65 & 24.01 & 23.86 & 23.88 & 24.81 & \\
\hline 0.12 & 0.06 & 0.06 & 0.07 & 0.1 & & 0.44 & 0.55 & 0.54 & 0.35 & 0.42 & \\
\hline 0 & 0.02 & 0 & 0 & 0 & & 0.02 & 0.01 & 0 & 0.01 & 0 & \\
\hline 99.60 & 99.50 & 99.80 & 100.00 & 100.00 & & 100.30 & 101.00 & 101.00 & 100.30 & 100.10 & \\
\hline 1.837 & 1.876 & 1.880 & 1.848 & 1.871 & & 1.983 & 1.990 & 1.990 & 1.983 & 1.983 & \\
\hline 0.163 & 0.124 & 0.120 & 0.152 & 0.129 & & 0.017 & 0.010 & 0.010 & 0.017 & 0.017 & \\
\hline 0.065 & 0.037 & 0.102 & 0.067 & 0.022 & & 0.016 & 0.023 & 0.024 & 0.017 & 0.019 & \\
\hline 0.003 & 0.005 & 0.004 & 0.003 & 0.004 & & 0.002 & 0.001 & 0.000 & 0.000 & 0.001 & \\
\hline 0.020 & 0.014 & 0.021 & 0.023 & 0.026 & & 0.023 & 0.024 & 0.022 & 0.021 & 0.019 & \\
\hline 0.073 & 0.066 & 0.064 & 0.070 & 0.067 & & 0.048 & 0.043 & 0.047 & 0.049 & 0.039 & \\
\hline 0.002 & 0.002 & 0.003 & 0.001 & 0.001 & & 0.002 & 0.001 & 0.002 & 0.002 & 0.002 & \\
\hline 0.828 & 0.877 & 0.847 & 0.847 & 0.875 & & 0.966 & 0.947 & 0.953 & 0.964 & 0.928 & \\
\hline 1.041 & 1.028 & 0.951 & 1.013 & 1.039 & & 0.915 & 0.922 & 0.916 & 0.924 & 0.963 & \\
\hline 0.009 & 0.004 & 0.004 & 0.005 & 0.007 & & 0.031 & 0.038 & 0.038 & 0.024 & 0.030 & \\
\hline 0.000 & 0.001 & 0.000 & 0.000 & 0.000 & & 0.001 & 0.000 & 0.000 & 0.000 & 0.000 & \\
\hline 4.040 & 4.034 & 3.996 & 4.030 & 4.040 & & 4.003 & 3.999 & 4.001 & 4.002 & 4.003 & \\
\hline 42.7 & 44.5 & 45.5 & 43.9 & 44.2 & & 47.6 & 48.2 & 46.6 & 47.3 & 46.9 & \\
\hline 3.7 & 3.3 & 3.4 & 3.6 & 3.4 & & 2.3 & 2 & 2.5 & 2.2 & 2.5 & \\
\hline 53.6 & 52.2 & 51.1 & 52.5 & 52.5 & & 48.5 & 47.7 & 49.3 & 48.6 & 48.7 & \\
\hline 91.9 & 93 & 93 & 92.4 & 92.9 & & 95.7 & 96 & 95.3 & 95.8 & 95.4 & \\
\hline
\end{tabular}



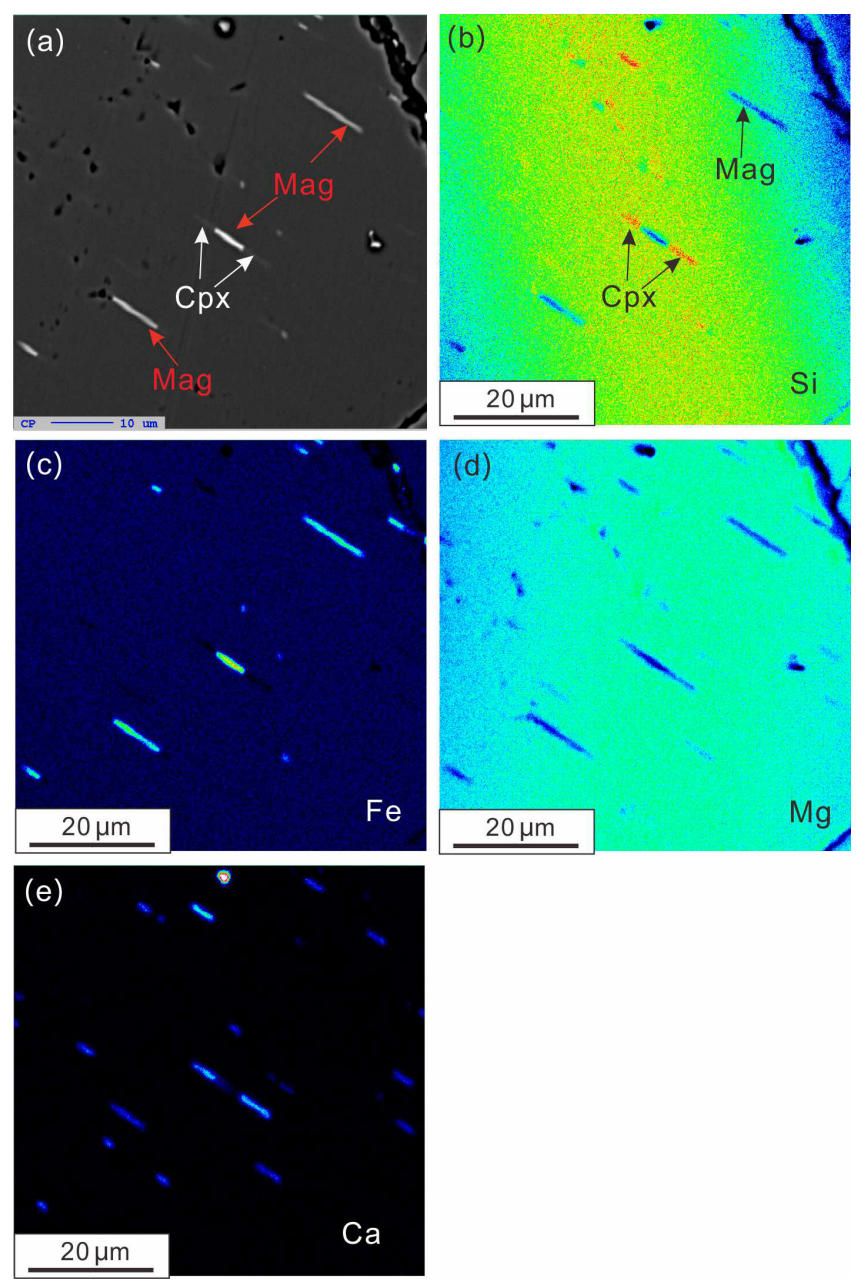

Figure 4. (a) BSE image of the clinopyroxene and magnetite exsolution lamellae in olivine. X-ray element maps show chemical variations in clinopyroxene and magnetite exsolution lamellae in olivine from type 3 dunite with Cr-poor spinel: (b) silicon, (c) iron, (d) magnesium and (e) calcium. For each element, the color scheme reflects amount of element abundance (blue is low and red is high). Abbreviations: Cpx, clinopyroxene; Mag, magnetite.

light brown and rectangular lamellae with preferred orientation in coarse-grained olivine of type 3 dunite that could not be identified.

\section{Major element and isotope chemistry}

\subsection{Major element chemistry of olivine}

Figure 7a and b compare Fo vs. $\mathrm{NiO}$ and $\mathrm{MnO}$, respectively. Figure 7 a shows that olivine compositions from harzburgite and the three types of dunite overlap to a large degree. However, forsterite contents in olivine type 1 dunite envelopes and dunite lenses with Cr-rich spinel reach somewhat higher values of Fo91.8 and Fo92.2, respectively, than harzburgite (Fo91.2) or dunite lenses with Cr-poor spinel (Fo90.7).
In Fig. $7 \mathrm{~b}$ the olivine compositions of the different source rocks are presented in a $\mathrm{MnO}$ vs. Fo component diagram, again documenting similar compositions of olivines in harzburgites and type 3 dunite. Olivine of dunite that envelopes chromitite lenses shows a higher Fo component; the respective values of olivine from type 2 dunite lenses are even higher.

\subsection{Li isotope chemistry of olivine}

Lithium isotope compositions, the respective amounts of forsterite component of olivine, as well as selected chemical parameters of accompanying Cr-rich spinel of the harzburgite, and the three different types of dunite are listed in Table 2. Generally, the Li concentrations and $\delta^{7} \mathrm{Li}$ values of the olivines studied show large variations from 0.75 to $1.74 \mathrm{ppm}$ and $6.19 \%$ to $+14.72 \%$, respectively, and they are negatively correlated (Fig. 8). Note that the olivines in harzburgite exhibit the lowest amounts of $\mathrm{Li}(0.8 \mathrm{ppm}$ on average; range of $0.75-0.89 \mathrm{ppm}$ ) and the highest concentrations of $\delta^{7} \mathrm{Li}$ (average of $13.8 \%$; range of $11.82-14.72 \mathrm{ppm}$ ), whereas those from type 1 dunite enveloping chromitite lenses have the highest amounts of $\mathrm{Li}$ (1.6 ppm on average; range of $1.48-1.74 \mathrm{ppm}$ ) and the lowest $\delta^{7} \mathrm{Li}$ concentrations (average of $7.1 \%$; range of $6.19 \%$; $-7.98 \%$ ). Li contents of olivines from type 2 and type 3 dunite lenses vary widely between 0.94 and $1.64 \mathrm{ppm}$, but some olivines of the type 2 dunite lenses have considerably higher amounts of Li (Fig. 8). The $\delta^{7} \mathrm{Li}$ values of olivine in the type 3 dunite lenses are in general higher $(10.25 \%$ - $14.2 \%$ ) than those of the type 2 dunite lenses $(6.77 \%$ o-10.76\%o). In Fig. 9 a series of correlation diagrams display the amount of $\mathrm{Li}$ (in ppm) and the $\delta^{7} \mathrm{Li}$ values (in \%o) in olivine relative to the Fo component in olivine and the $\mathrm{NiO}$ and $\mathrm{MnO}$ content, as well as $\mathrm{Cr} \#$ of the spinels in the different lithological types studied. These diagrams indicate that dunite formed in different environments and/or stages. Note, however, that olivine from harzburgite and type 3 dunite lenses with Cr-poor chromite exhibit quite similar chemical characteristics.

\subsection{Chemical composition of the spinel supergroup minerals}

Spinel supergroup minerals (Bosi et al., 2019) are significant indicators that allow us to distinguish the different host rocks and gain insight into possible geotectonic provenance. In Fig. 10, discrimination diagrams were chosen to characterize the spinel compositions; the respective analyses are given in Table 3. Figure 10c, a $\mathrm{Cr} \#[100 \times \mathrm{Cr} /(\mathrm{Cr}+\mathrm{Al})]$ vs. $\mathrm{Mg} \#$ $\left[100 \times \mathrm{Mg} /\left(\mathrm{Mg}+\mathrm{Fe}^{2+}+\mathrm{Mn}\right)\right]$ diagram, documents a compositional trend with increasing $\mathrm{Cr} \#$ and $\mathrm{Mg} \#$ from type 3 dunite, via harzburgite and type 1 dunite enveloping chromitite, to type 2 dunite. Magnesiochromite in type 2 dunite lenses, both in the matrix and as inclusions in olivine, is typically small and euhedral and shows Cr\# between 66 and 67 

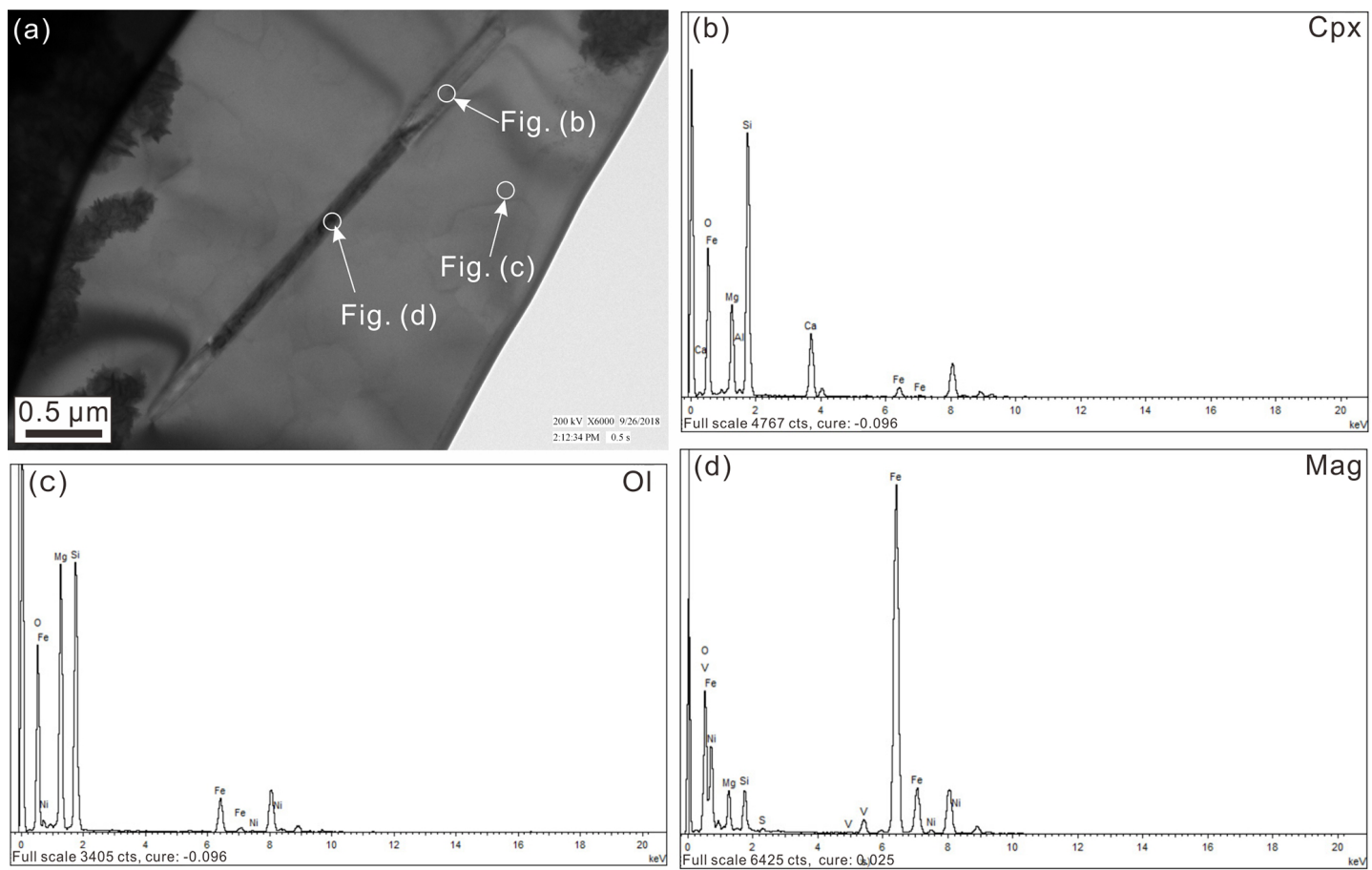

Figure 5. (a) View of a TEM olivine foil containing clinopyroxene and magnetite exsolution lamellae. (b) EDX spectrum collected from the central part of the clinopyroxene. (c) EDX spectrum collected from the central part of the olivine. (d) EDX spectrum collected from the central part of the magnetite. Abbreviations: Ol, olivine; Cpx, clinopyroxene; Mag, magnetite.

and $\mathrm{Mg \#}$ between 52 and 54, whereas spinel. in the type 3 dunite lenses yields Cr\# between 19 and 20 and Mg\# between 72 and 78. The diagram also documents that only the spinel supergroup minerals of the type 2 dunites are magnesiochromite, whereas those of the three other lithological types are spinel. The analyses of magnesiochromite from the type 2 dunite lenses fall into the compositional field of ophiolitic chromitites (Kamenetsky et al., 2001) and are located between the two fields of abyssal and forearc peridotites (Fig. 10c).

The $\mathrm{Cr} \#$ vs. $\mathrm{TiO}_{2}$ diagram (Fig.10b) documents low amounts of $\mathrm{TiO}_{2}(<0.1 \mathrm{wt} \%)$ in spinel supergroup minerals of the type 1 dunite that envelopes chromitite and in the harzburgite; the respective $\mathrm{Cr} \#$ is about 50 and 30 . The type 3 and type 2 dunite lenses contain spinel supergroup minerals with $\mathrm{TiO}_{2}$ contents between 0.13 and 0.23 . The correlation between the Cr\# of spinel supergroup minerals and the Fo content of the adjacent olivine reveals a compositional trend within the olivine-spinel mantle array (OSMA; Arai, 1994; Fig. 10a).

\subsection{Chemical composition of clinopyroxene}

Clinopyroxene is essentially diopsidic with compositions between 31.2 and $50.1 \mathrm{~mol} \%$ En end-member (Table 4). Correlation diagrams for selected oxides are shown in Fig. 11.

In general, the clinopyroxenes in the harzburgite have the lowest Mg\#, between 90.7 and 93.0. In the type 1 dunite that envelopes chromitite lenses, the $\mathrm{Mg} \#$ is between 91.7 and 93.7. In the type 3 dunite lenses the $\mathrm{Mg} \#$ is similar (95.396.0), but in the type 2 dunite lenses $\mathrm{Mg \#}$ is considerably higher and varies between 91.9 and 93.0. The $\mathrm{Al}_{2} \mathrm{O}_{3}$ content of clinopyroxene is variable, lying in the range of $4.28 \mathrm{wt} \%$ $5.45 \mathrm{wt} \%$ in the harzburgites, $1.56 \mathrm{wt} \%-3.29 \mathrm{wt} \%$ in the type 1 dunite enveloping chromitite, $0.78 \mathrm{wt} \%-0.86 \mathrm{wt} \%$ in the type 2 dunite lenses and $3.48 \mathrm{wt} \%-5.24 \mathrm{wt} \%$ in the type 3 dunite lenses.

The contents of $\mathrm{Cr}_{2} \mathrm{O}_{3}$ in clinopyroxene of the peridotites range from $0.1 \mathrm{wt} \%$ to $1.32 \mathrm{wt} \%$, and $\mathrm{Na}_{2} \mathrm{O}$ contents are below $1.0 \mathrm{wt} \%$. The clinopyroxenes of harzburgites show the highest amounts of $\mathrm{Cr}_{2} \mathrm{O}_{3}, \mathrm{Na}_{2} \mathrm{O}$ and $\mathrm{TiO}_{2}(0.16$ wt \%$0.25 \mathrm{wt} \%$ ) compared to the remaining peridotites. The amount of $\mathrm{TiO}_{2}$ in clinopyroxene is also relatively high in the type 3 dunite lenses $(0.12-0.19)$, whereas it is significantly lower in the type 1 dunite enveloping chromitite and in the type 2 dunite.

\section{Discussion}

\subsection{Origin of different dunite types}

The bulk rock characteristics and $\mathrm{Li}$ isotope ratios of the different types of dunite from the Purang ophiolite, as well as their corresponding mineral compositions, are quite different. The type 3 dunite lenses contain chromian spinel with 

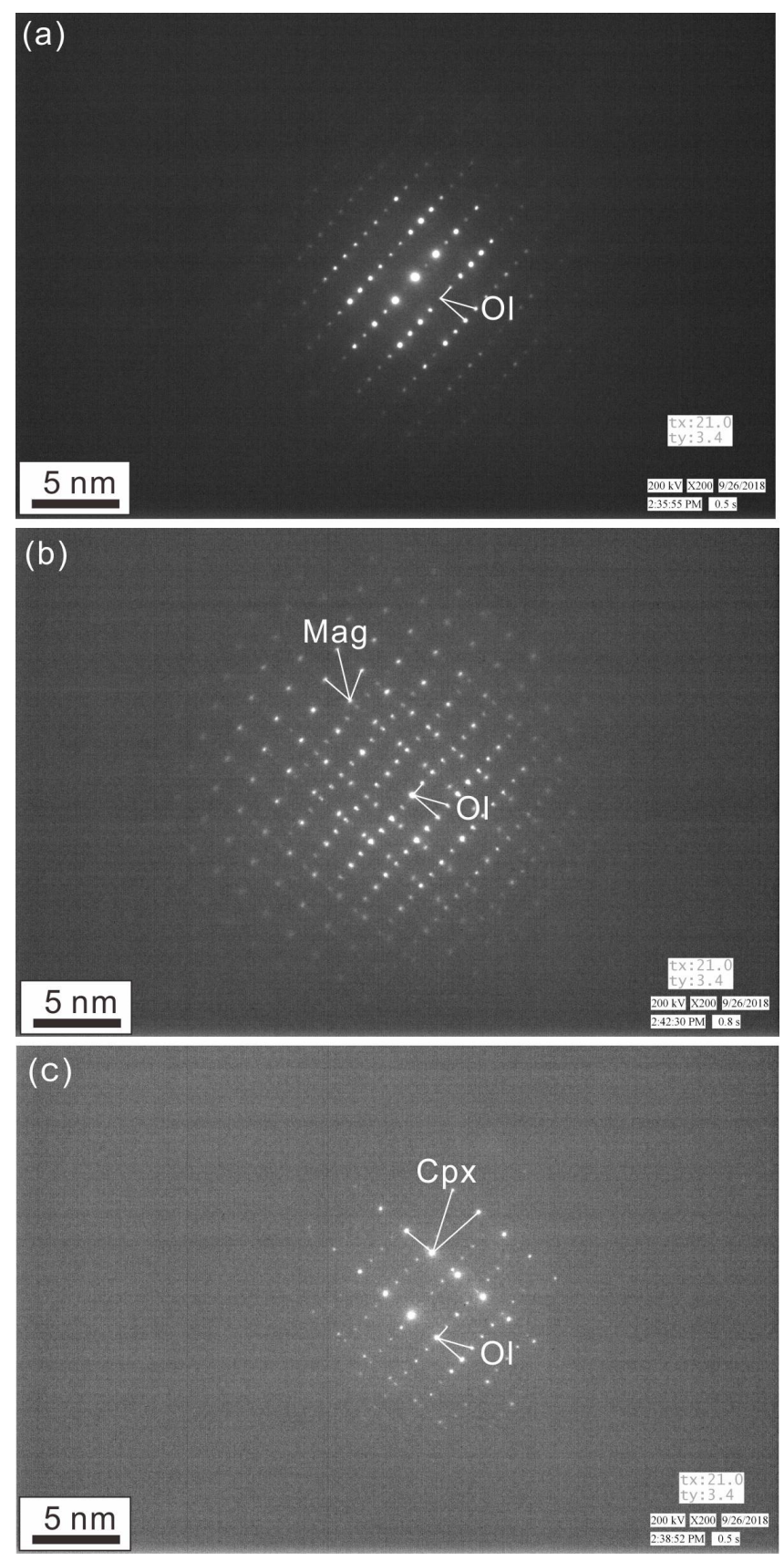

Figure 6. X-ray diffraction patterns from the TEM olivine foil shown in Fig. 5a: (a) olivine, (b) olivine and magnetite, (c) olivine and clinopyroxene. Abbreviations: Ol, olivine; $\mathrm{Cpx}$, clinopyroxene; Mag, magnetite.

the lowest Cr\# observed, which may have experienced interaction with an aluminum-rich melt. In addition, exsolution textures were produced in type 3 dunite during uplift (Xiong et al., 2016; Fig. 10a). Note that the composition of chromian spinel and olivine from the type 3 dunite is similar to that in abyssal peridotite (Zhou et al., 2005; Arai and Miura, 2016). Note also that the type 2 dunite lenses and the type 1 dunite enveloping chromitite differ from the type 3 dunite. The type 1 dunites were possibly more intensely affected by an interaction with melt. A similar behavior was reported by Zhou et al. (2005), who suggested that the melt in a supra-subduction zone setting would be of a boninite composition, whereas the type 1 dunite envelope is considered to be formed by the reaction of a subduction-related melt with lherzolite or wehrlite (Zhou et al., 2005; Xiong et al., 2015; Zhang et al., 2019a, b). In an olivine vs. chromian spinel mantle-array diagram (Arai, 1994), the type 3 dunites and the harzburgites plot entirely within the area defined by abyssal peridotite, with approximately $8 \%$ and $10 \%$ partial melting (Fig. 10a), indicating MOR peridotite. In contrast, type 1 dunite envelopes and type 2 dunites, which can be estimated to have experienced about $20 \%$ and $35 \%$ partial melting, respectively, show compositional features similar to subduction zone (SSZ) peridotite (Fig. 10a), which may be the result of a multistage development.

The formation of high-Cr chromitites, dunites and refractory harzburgites is thought to result from varying degrees of reaction between a boninite-like melt and Cpxbearing harzburgite (Zhou et al., 2005). In addition, most of the dunite envelopes are found only around disseminated chromitites, not the massive varieties (Fig. 2b). The prevailing view that podiform chromitites form only in SSZ settings by reaction between hydrous boninitic melts and mantle peridotites in the shallow mantle (Zhou et al., 1996, 2005; Uysal et al., 2005; Xiong et al., 2015) is based on the study of large chromitite bodies.

Kelemen et al. (1990) provided reaction experiments between a melt of olivine tholeiite and harzburgite at $5 \mathrm{kbar}$ and $1050-1150{ }^{\circ} \mathrm{C}$ and demonstrated that the amount of $\mathrm{SiO}_{2}$ in the solid phase gradually increases with the consumption of the harzburgite. The $\mathrm{Mg} /(\mathrm{Mg}+\mathrm{Fe})$ ratio in the solid phase also decreases until the harzburgite is finally consumed. Their study showed that a similar process might be expected during interaction with depleted mantle peridotites, e.g., when an arc of magma rises through the mantle lithosphere of the overriding plate. This process involves extensive reaction events between melt, olivine, orthopyroxene and spinel. Sakae and Jun-Ichi (2007) pointed out that through this boninitic melt-rock reaction a large number of different dunite lenses can be produced in a peridotite massif in New Zealand. The type 2 dunite lenses with Cr-rich spinel form intercalations within harzburgite, and the compositions of olivine, clinopyroxene and chromian spinel show gradual changes from harzburgite. Therefore, the type 2 dunite lenses may be the remnants of a mantle peridotite after high partial melting, and the type 3 dunite with Cr-poor spinel could result from an in situ reaction between an aluminum-enriched melt and peridotite. The type 1 dunite envelopes are probably a result of a melt-peridotite reaction.

Several authors have described clinopyroxene and magnetite intergrowth structures in olivine and interpreted them as exsolution features (e.g., Arai, 1978; Moseley, 1984; 

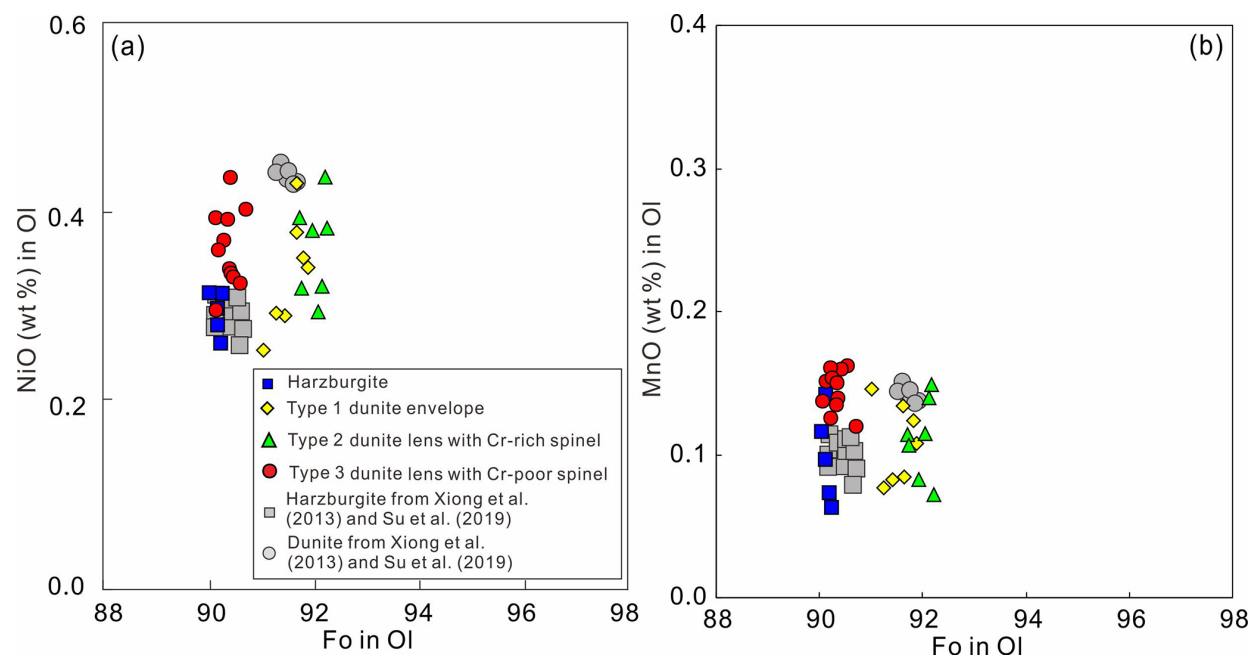

Figure 7. (a) $\mathrm{NiO}$ and (b) $\mathrm{MnO}$ vs. Fo component in olivine of the different lithologies of the Purang ophiolite.

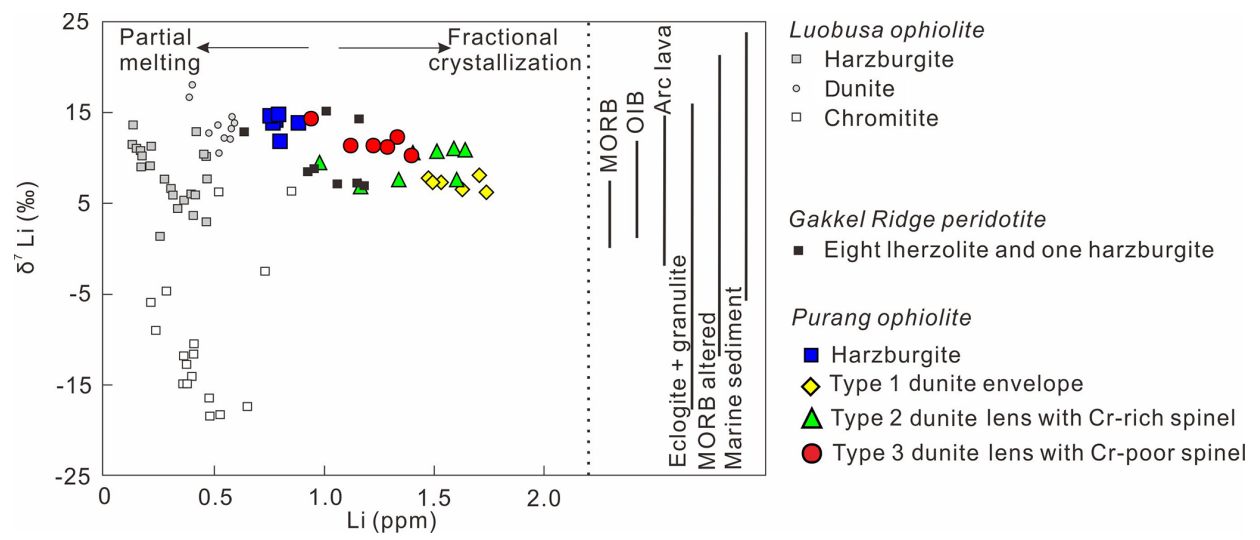

Figure 8. Diagram of Li vs. $\delta^{7} \mathrm{Li}$ for olivine in different Purang ophiolitic rock types. Olivine data of the Luobusa (Su et al., 2016) and Trinity (Lundstrom et al., 2005) ophiolites and the Gakkel Ridge peridotites (Gao et al., 2011) plotted for comparison. The $\delta^{7} \mathrm{Li}$ ranges of MORB, OIB, arc lava, eclogite + granulite, altered MORB and marine sediment are from Tomascak et al. (2016) and references therein. The two arrows, "partial melting" and "fractional crystallization" are defined based on the Trinity data (Lundstrom et al., 2005).

Xiong et al., 2017; Liang et al., 2014, 2018). Ashworth and Chambers (2000) and Ren et al. (2008), however, interpreted them as symplectites. The structures observed in the Purang dunites of the present study are here interpreted as exsolution lamellae. Exsolution of magnetite from olivine could presumably represent either a decomposition product of a solid solution between olivine and laihunite $\left[\mathrm{Fe}^{2+} \mathrm{Fe}_{2}^{3+}\left(\mathrm{SiO}_{4}\right)_{2}\right]$ or an oxidization product of $\mathrm{Fe}^{2+}$ in the olivine (Moseley, 1984).

Olivine accommodates extremely small quantities of $\mathrm{Ca}^{2+}$ and $\mathrm{Na}^{+}$ions in its crystal lattice due to the larger ionic radii of these elements compared to those of $\mathrm{Fe}^{2+}, \mathrm{Mg}^{2+}$ and $\mathrm{Mn}^{2+}$. Olivine is thus not expected to exsolve clinopyroxene. Experimental studies on the olivine-melt system show that the higher the contents of $\mathrm{CaO}, \mathrm{Na}_{2} \mathrm{O}$ and $\mathrm{FeO}$ in the melt, the higher the Ca content in the olivine (Libourel, 1999). In this study, olivine grains with exsolution microstructures point to a relatively high $\mathrm{CaO}$ content prior to exsolution (Fig. 4). The $\mathrm{CaO}$ content in the olivine cannot indicate fractional crystallization, nor can it be due to to the effects of oxygen fugacity, temperature, and pressure (Libourel, 1999). Thus, the variation in $\mathrm{CaO}$ content of olivine in the dunite from the Purang ophiolite (Fig. 4) may be related to later modification by melt or fluid. The clinopyroxene in the rodlike intergrowths of magnetite in the type 3 dunite olivine grains is aligned in the same direction as the needle-like intergrowths (Figs. 4, 5), indicating their simultaneous exsolution. It has been documented that clinopyroxene can crystallize from hydrothermal fluids at temperatures higher than $750^{\circ} \mathrm{C}$ (Python et al., 2007; Akizawa et al., 2011; Akizawa and Arai, 2014). The association of clinopyroxene and magnetite and the presence of interstitial clinopyroxene in the $\mathrm{Pu}$ rang ophiolite suggest the involvement of hydrothermal fluids during the formation of the dunite. Hence, the reactant 

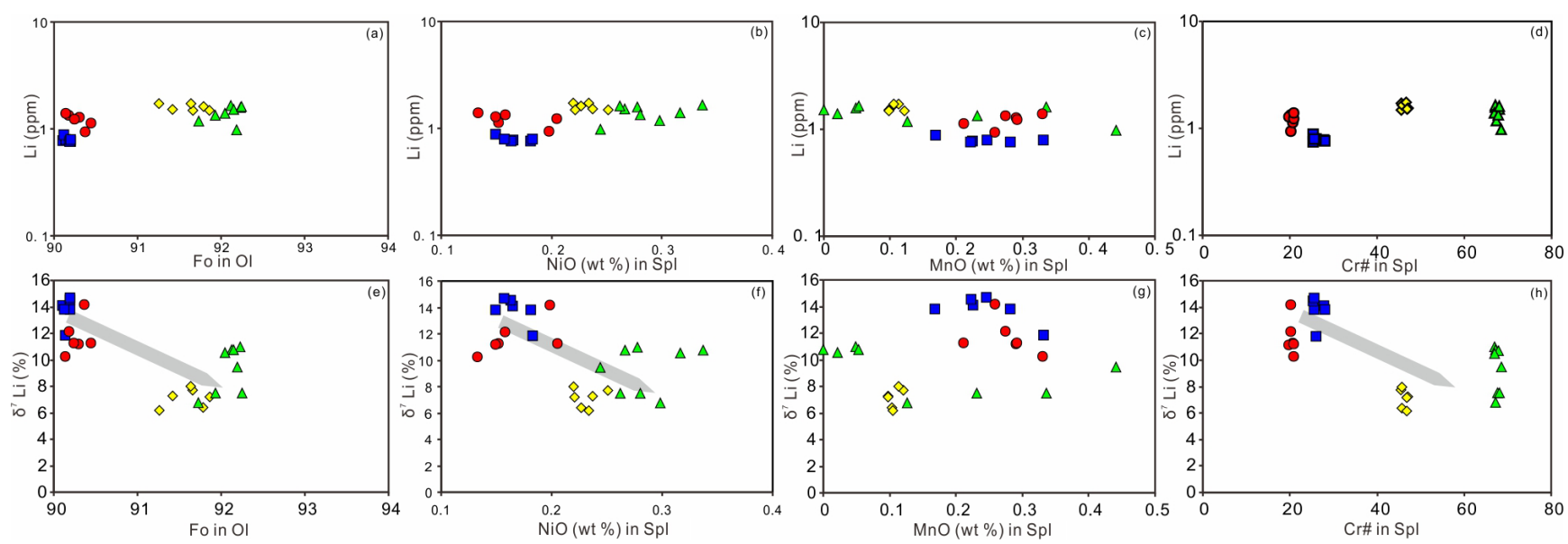

Figure 9. Correlation diagrams of $\mathrm{Li}$ and $\delta^{7} \mathrm{Li}$ vs. Fo in olivine, $\mathrm{NiO}, \mathrm{MnO}$ and $\mathrm{Cr} \#$ in chromian spinels for the Purang dunite and harzburgite. Arrows represent the magma differentiation trend with high partial melting (Lundstrom et al., 2005; Su et al., 2016). Symbols are the same as in Fig. 7.

fluids could have originated from hydrothermal fluids. Reequilibration between olivine and fluids at high temperatures could produce solid solutions with $\mathrm{Ca}^{2+}$ and $\mathrm{Na}^{+}$in olivine. This feature has been well documented in dunites of the $\mathrm{Lu}$ obusa ophiolite in the eastern part of the Yarlung-Zangbo suture zone (Ren et al., 2008). Because of the rapid uplift and cooling of the Purang peridotite (Liu et al., 2014), the exsolution lamellae in the olivine grains do not show plastic deformation; thus, their primary exsolution features are well preserved.

\subsection{Li isotope fractionation of the different types of dunite and harzburgite}

The isotopes of $\mathrm{Li},{ }^{6} \mathrm{Li}$ and ${ }^{7} \mathrm{Li}$ can be easily fractionated because of their large mass difference $(\sim 15 \%)$, resulting in large $\delta^{7} \mathrm{Li}$ variation in the terrestrial environment. For example, the $\delta^{7} \mathrm{Li}$ value of seawater is $\sim+32 \%$ and that of $\mathrm{N}-\mathrm{MORB}$ and MORB sources ranges from $\sim+1.5 \%$ to $+6.5 \%$, whereas altered MORB has a larger range from $-2 \%$ o to $+14 \%$ (Chan et al., 1999; Decitre et al., 2002; Lundstrom et al., 2005; Vils et al., 2008). During subduction, $\mathrm{Li}$ in subducted slabs can be easily mobilized and carried into the overlying mantle wedge by fluids (Ishikawa et al., 2005; Savov et al., 2007). Li isotopic signatures developed in the crust and mantle can be used to study mantle heterogeneity. Abyssal peridotites have Li concentrations of $<3 \mathrm{ppm}$, which are lower than those of rocks formed by a melt-peridotite reaction. Based on the dissolution of olivine during the process of partial melting, $\mathrm{Li}$ isotopic diversities of the different peridotites studied can be seen as the result of different amounts of melt extraction and high-temperature hydrothermal alteration (Su et al., 2016, 2017; Xiao et al., 2017) (Fig. 8).
The different types of olivine-rich rocks discovered in the Purang ophiolite formed due to different mechanisms. In olivine the Fo end-member content correlates with the different $\mathrm{Li}$ isotope characteristics in the various peridotites (Fig. 9). The Purang peridotites have heavy Li isotopes with high $\delta^{7} \mathrm{Li}$ values of 6.19-14.72, which are similar to arc lavas but also overlap with values found in metamorphic products such as eclogites and granulites, as well as altered MORBs and marine sediments (Fig. 8). Note that the type 1 dunite enveloping chromitite has higher amounts of $\mathrm{Li}$ than the harzburgite but the lowest values of $\delta^{7} \mathrm{Li}$. Since $\mathrm{Li}$ is highly mobile, it is sensitive to low-temperature fluid-rock interaction (Chan et al., 2002). Lithium and (preferentially) ${ }^{6} \mathrm{Li}$ move from olivine grains to the hydrothermal fluid during serpentinization, and as a result olivine becomes Li-depleted and isotopically heavier in Li (Decitre et al., 2002; Lundstrom et al., 2005; Wimpenny et al., 2010; Wunder et al., 2010; Su et al., 2016). In addition, crustal contamination may lead to an increase in the Li content in the magma and a change of its ${ }^{7} \mathrm{Li}$ isotopic composition, especially during magma ascent and ophiolite emplacement (Teng et al., 2004). The Purang peridotite is high in $\mathrm{MgO}$ and rare-earth elements (REE) (Li et al., 2015; Xiong et al., 2018), and the Li content in olivine is very low (Table 2). This means that the process of crustal contamination is negligible. Teng et al. (2011), Xiao et al. (2016) and Bai et al. (2017) demonstrated the possibility of an intense exchange of chemical components between olivine and chromian spinel. It is widely accepted that Fe diffuses from olivine to chromite as the temperature decreases (Mg does the opposite), thus increasing the Fo component of olivine (Su et al., 2015; Xiong et al., 2015; Bai et al., 2017). Previous studies have suggested (e.g., Lundstrom et al., 2005; Tomascak et al., 2016) that because ${ }^{6} \mathrm{Li}$ diffuses slightly faster than ${ }^{7} \mathrm{Li}$ inside minerals, a negative anomaly of about $10 \%$ - $20 \%$ should be produced in olivine. This diffu- 

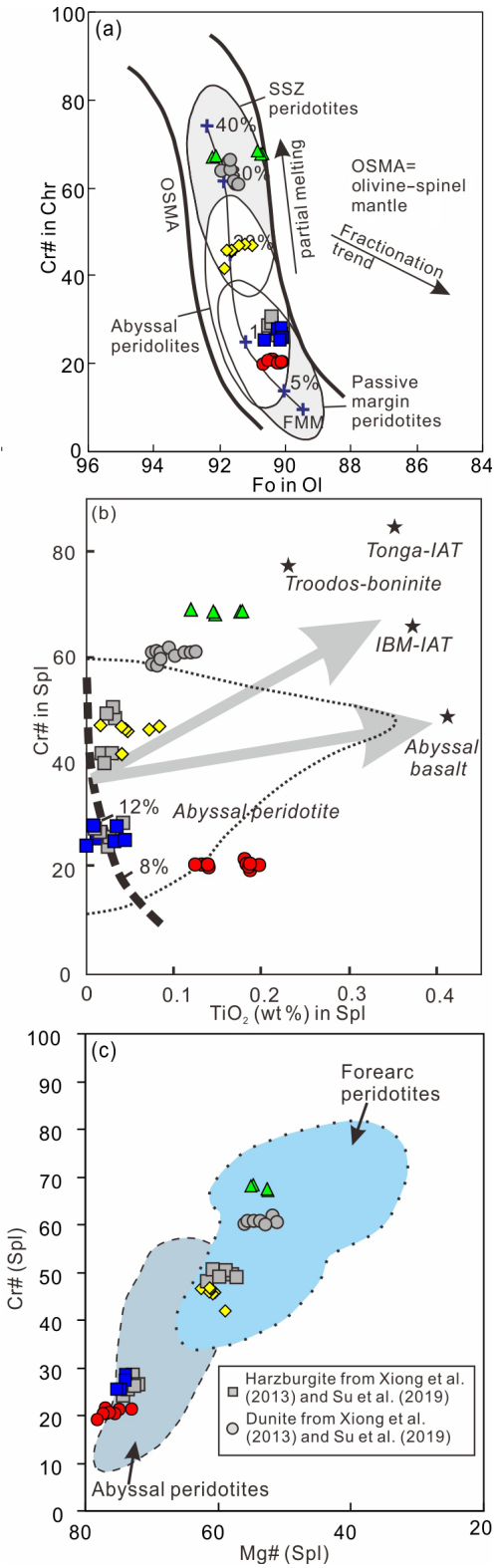

Figure 10. (a) Fo component in olivine vs. Cr\# of chromian spinel of the Purang peridotite (Pearce et al., 2000; Ozawa, 1994; Pagé et al., 2008; Dick and Bullen, 1984). (b) Compositional variations in Cr\# vs. $\mathrm{TiO}_{2}$ (wt \%) content of spinel (Pearce et al., 2000) of peridotite samples of the Purang ophiolite. (c) Compositional variations in Cr\# vs. Mg\# of spinel (Pearce et al., 2000) from peridotite samples of the Purang ophiolite. Fields for abyssal peridotite are taken from Dick and Bullen (1984), Bonatti and Michael (1989), Hébert et al. (1990), Johnson et al. (1990), Ishii et al. (1992), Arai (1994), Parkinson and Pearce (1998), Pearce et al. (2000) and Parkinson et al. (2003). The degrees of melt extraction calculated based on spinel composition in (a) are based on the empirical formula of Hellebrand et al. (2001). The arrows and thick dashed line in Fig. 10b show interaction between MORB-like melt and a supra-subduction zone melt (Pearce et al., 2000). Symbols are the same as in Fig. 7.
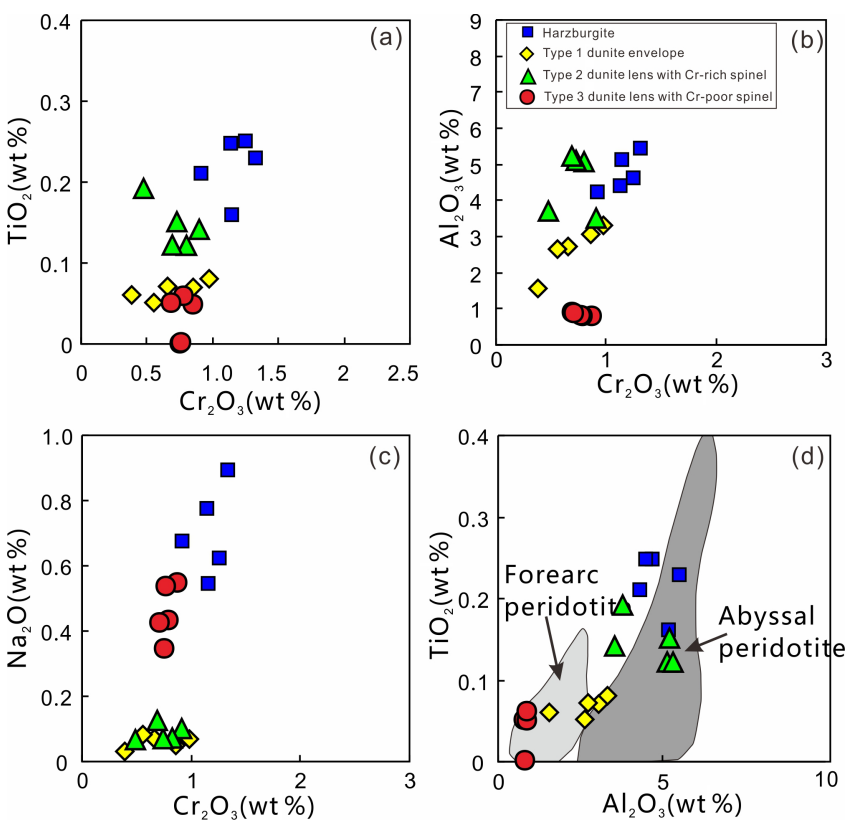

Figure 11. Compositional ranges of selected oxides for clinopyroxene from different lithologies of the Purang ophiolite. Data for abyssal peridotite and fore-arc peridotite are from Pagé et al. (2008).

sion mechanism may explain the slightly negative correlation between $\mathrm{Li}$ and $\delta^{7} \mathrm{Li}$ observed in the Purang olivines of the different ultrabasic rocks (Fig. 8), but it does not explain the variability of the entire dataset of $10 \%$ of $\delta^{7} \mathrm{Li}$ difference and its correlation with magma differentiation indicators between the different dunites. The decreased $\delta^{7} \mathrm{Li}$ trend of olivine in dunite was explained as a result of $\mathrm{Li}$ diffusion from melt in a melt conduit to the host peridotite during melt-harzburgite interaction (Su et al., 2016).

Chemically or isotopically driven intragranular diffusion may affect the Li concentration of a mineral, depending on whether its growth occurred from a fluid or a melt (Tomascak et al., 2016). Even if the Li isotopes take more time to achieve compositional uniformity between melt and crystals than the Li abundance (Richter et al., 2014), the Li content in Purang peridotites is similar, whereas the $\delta^{7} \mathrm{Li}$ values have some unclear variation (Fig. 9). The $\delta^{7} \mathrm{Li}$ values of forsterite of the type 2 dunite lenses and the type 1 dunite enveloping chromitite are lower than those of the harzburgite and the type 3 dunite lenses. The same features are evident in $\mathrm{NiO}$ and $\mathrm{Fo}$ of olivine and $\mathrm{Cr} \#$ of spinel, respectively, which show a negative correlation with the $\delta^{7} \mathrm{Li}$ values (Fig. 9).

Lithium is a moderately incompatible element during mantle melting processes and magma differentiation (Brenan et al., 1998). The concentration of $\mathrm{Li}$ in the magma increases as the degree of differentiation increases (e.g., Hamelin et al., 2009; Marks et al., 2007; Weyer and Seitz, 2012; Ackerman et al., 2015). The Purang olivine shows a tendency towards increased Li with a decrease in Fo component (Fig. 9). 
In addition, the $\mathrm{Li}$ content of olivine is negatively correlated with $\mathrm{NiO}$ and also negatively correlated with $\mathrm{Cr} \#$ in spinel supergroup minerals(Fig. 9). These trends are consistent with trends that result from magma differentiation. Marks et al. (2007) found evidence that olivine fractionation drives the derived magma to move in the direction of high $\mathrm{Li}$ and that this elevated $\mathrm{Li}$ trend is thought to be related to the redox conditions of the magma. The diffusion process alone does not explain the preferred enrichment of $\delta^{7} \mathrm{Li}$ in the melt relative to olivine phenocrysts. The Purang peridotite acts as a quasi-stable aquifer system that can carry large amounts of fluids that were introduced during the SSZ subduction (Xiong et al., 2018). A large number of studies have demonstrated that $\mathrm{Li}$, in general, is an element that can easily transport via a fluid phase (Brenan et al., 1998; Su et al., 2016, 2018). With respect to questions related to isotope fractionation processes, Chan et al. (1999) were able to show that ${ }^{7} \mathrm{Li}$ becomes preferentially enriched in the fluid phase. Su et al. $(2015,2016)$ have demonstrated that during the subduction of the basaltic oceanic crust and overlying sediments, fluids may become released and percolate through the overlying mantle wedge; magma that is generated in such an environment can thus incorporate the $\mathrm{Li}$ isotope characteristics of these fluids.

\subsection{Tectonic setting of the Purang ophiolite}

The Purang ophiolite is one of the numerous ophiolite bodies located along the Yarlung-Zangbo suture zone in southern Tibet, which are considered to be either remnants of the Neo-Tethyan lithosphere emplaced during the collision between the Indian and Asian plates or as ancient subcontinental lithospheric mantle domains (Gong et al., 2016). It consists chiefly of mantle peridotites locally accompanied by gabbros, dikes and solidified lavas. The solidified lavas range from arc tholeiites to boninitic and OIB-like basalts. Most of the peridotites have "U-shaped", chondrite-normalized REE patterns, which indicate the re-fertilization of depleted peridotites in a supra-subduction zone environment (Xiong et al., 2018).

However, the presence of both type 2 and type 3 dunite pods in the Purang peridotites and the presence of magnetite + clinopyroxene exsolution lamellae in olivine of the type 3 dunite provide important clues to the tectonic environment in which this ophiolite formed. There is strong evidence for a multistage origin of the Purang peridotites. After having reached relatively shallow levels in the upper mantle, the peridotites were trapped in a supra-subduction zone wedge, where they underwent interaction with SSZ melts and fluids (Xiong et al., 2019c). Initially, the hydrous melting of the peridotite produced Mg-rich magmas, which reacted with the peridotites to form dunite pods characterized by $\mathrm{Mg}$-rich olivine and high-Cr spinel. In some ophiolites, such as Luobusa, the dunite pods are closely associated with podiform chromitites. A second stage of melting in the Purang peri- dotites produced boninitic magmas via lower degrees of partial melting, which were relatively rich in $\mathrm{Ti}^{4+}, \mathrm{Al}^{3+}, \mathrm{Ca}^{2+}$, $\mathrm{Na}^{1+}$ and $\mathrm{Fe}^{3+}$. During the reaction of these melts with the peridotites, small amounts of these elements may have become incorporated into the newly crystallized olivine. During subsequent cooling, they very likely became exsolved as lamellae of magnetite (containing $\mathrm{Fe}^{3+}, \mathrm{Ti}^{4+}$ ) and clinopyroxene (containing $\mathrm{Al}^{3+}, \mathrm{Ca}^{2+}$ and $\mathrm{Na}^{1+}$ ). Thus, our preferred explanation for the origin and evolution of the Purang ophiolite is that the mantle peridotites formed in a MOR environment and were then modified by later-stage melts and fluids in a SSZ setting during intra-oceanic subduction along the Indus-Yarlung-Zangbo suture (see Zhou et al., 1996, 2005; Malpas et al., 2003; Hébert et al., 2003; Dubois-Côté et al., 2005; Bédard et al., 2009; Liu et al., 2010; Xu et al., 2011; Xiong et al., 2013; Su et al., 2019). The discovery of a large number of water-bearing minerals in the Purang chromitite is a further indicator of fluid exchange processes (Xiong et al., 2013, 2018). The above-described characteristics and discussed processes for the Purang ophiolite are consistent with the geochemical behavior of $\mathrm{Li}$ isotopes in a subduction-zone setting, as described by Marschall et al. (2007), Wunder et al. (2006) and Yamaji et al. (2001), who found evidence for a progressive release of fluid from the subducted plate that migrated into the overlying mantle wedge and caused a lowering of $\delta^{7} \mathrm{Li}$.

\section{Conclusions}

1. We recognized three types of dunite in the Purang ophiolite: type 1 dunite, which envelops podiform chromitite and contains $\mathrm{Cr}$-rich spinel with $\mathrm{Cr} \#=41.5-46.8$; type 2 dunite lenses containing magnesiochromite with $\mathrm{Cr} \#$ $=66.9-67.9$; and type 3 dunite lenses with spinel that shows Cr\# between 19.8 and 20.6. Olivine in the type 3 dunite exhibits exsolution lamellae of diopside and magnetite; such features are absent in type 2 dunite. The type 3 dunite probably formed by a reaction between harzburgite and an arc tholeiite magma that was relatively rich in $\mathrm{Ti}, \mathrm{Fe}^{3+}, \mathrm{Al}, \mathrm{Ca}$ and $\mathrm{Na}$, whereas the type 2 variety formed from interaction with boninitic melts containing high amounts of $\mathrm{Mg}$ and $\mathrm{Cr}$. Due to rapid cooling during tectonic emplacement of the rocks, the exsolution textures in olivine were produced and preserved; the compositional zoning observed in the spinel supergroup minerals also reflects a formation that occurred during uplift.

2. The Purang ophiolite contains rocks that have different amounts of $\mathrm{Li}$ and that also differ in $\delta^{7} \mathrm{Li}$ compositions. The Li isotopic variations in the various types of dunite are a result of different types of occurrence, i.e., as primary dunite at mid-ocean ridges or as dunite that experienced subsequent modification in a supra-subduction zone setting. Olivine from the harzburgite documents a 
negative correlation between the forsterite component of olivine and $\delta^{7} \mathrm{Li}$ values due to the diffusive influx of $\mathrm{Li}$ from interconnected melts. The $\delta^{7} \mathrm{Li}$ isotopic compositions of the dunites are similar to arc-like melts. However, there is also an overlap with MORB, OIB, or even $\mathrm{Li}$ that originates from sedimentary sources. The interacting melts leading to crystallization of magnesiochromite are inferred to have been depleted in Li content and enriched in ${ }^{6} \mathrm{Li}$ relative to ${ }^{7} \mathrm{Li}$, thus producing values inferred for highly dehydrated slabs. These different types of melts continuously and progressively reacted with the oceanic lithospheric mantle, resulting in the formation of dunite and chromitite and, in addition, accounting for the observed Li isotope heterogeneity.

Data availability. The data of this paper can be accessed from reliable public data repositories, by assigning digital object identifiers (DOIs) https://doi.org/10.5194/ejm-32-1-2020 (Miyawaki, 2020) and properly citing datasets as individual contributions, such as the journal of European Journal of Mineralogy.

Author contributions. FX, JY, ZL and XX undertook the fieldwork, collected the rock samples and acquired the different analytical data. FX, JY and HPS shaped the work's conception, studied the microscopic data and SEM features, and interpreted the elemental and isotope data. FX and HPS wrote the manuscript and finalized the submission. All authors have approved the submitted version.

Competing interests. The authors declare that they have no conflict of interest.

Special issue statement. This article is part of the special issue "To Christian Chopin, in recognition of 30 years of dedicated service to EJM". It is not associated with a conference.

Acknowledgements. We thank Qiu-Li Li, Guo-Qiang Tang and $\mathrm{Yu}$ Liu for their assistance with the SIMS analyses and the Key Laboratory of Nuclear Resources and Environment (East China Institute of Technology) for the microprobe analyses. We thank Professor Walter Maresch for his constructive comments on the paper. This research was co-supported by the Second Tibetan Plateau Scientific Expedition and Research Program (no. 2019QZKK0801), the National Key Research and Development Project of China (no. 2016YFC0600310), the State Scholarship Fund (no. 201904180031), the Key Laboratory of Deep-Earth Dynamics of Ministry of Natural Resources Fund (no. J1901-7), the National Natural Science Foundation of China (NNSFC; project nos. 41672046, 41641015, 41720104009, 41703036), the China Geological Survey (CGS; Project No. DD201190060), and the International Geological Correlation Project (no. IGCP-649).
Financial support. This research was co-supported by the Second Tibetan Plateau Scientific Expedition and Research Program (grant no. 2019QZKK0801), the National Key Research and Development Project of China (grant no. 2016YFC0600310), the State Scholarship Fund (grant no. 201904180031), the Key Laboratory of Deep-Earth Dynamics of Ministry of Natural Resources Fund (grant no. J1901-7), the National Natural Science Foundation of China (NNSFC; grant nos. 41672046, 41641015, 41720104009, 41703036), the China Geological Survey (CGS; grant no. DD201190060), and the International Geological Correlation Project (grant no. IGCP-649).

Review statement. This paper was edited by Patrick Cordier.

\section{References}

Abzalov, M. Z.: Chrome-spinels in gabbro-wehrlite intrusions of the Pechenga area, Kola Peninsula, Russia: emphasis on alteration features, Lithos, 43, 109-134, https://doi.org/10.1016/S00244937(98)00005-X, 1998.

Ackerman, L., Ulrych, J., Řanda, Z., Erban, V., Hegner, E., Magna, T., Balogh, K., Frána, J., Lang, M., and Novák, J. K.: Geochemical characteristics and petrogenesis of phonolites and trachytic rocks from the České Středohoří Volcanic Complex, the Ohře Rift, Bohemian Massif, Lithos, 224-225, 256-271, https://doi.org/10.1016/j.lithos.2015.03.014, 2015.

Akizawa, N. and Arai, S.: Petrology of mantle diopsidite from WadiFizh, northern Oman ophiolite: $\mathrm{Cr}$ and REE mobility by hydrothermal solution, Island Arc., 23, 312-323, https://doi.org/10.1111/iar.12074, 2014.

Akizawa, N., Arai, S., Tamura, A., Uesugi, J., and Python, M.: Crustal diopsidites from the northern Oman ophiolite: evidence for hydrothermal circulation through suboceanic Moho, J. Mineral. Petrol. Sci., 106, 261-266, https://doi.org/10.2465/jmps.110621b, 2011

Arai, S.: Chromian spinel lamellae in olivine from the Iwanai-dake peridotite mass, Hokkaido, Japan, Earth Planet. Sc. Lett., 39, 267-273, https://doi.org/10.1016/0012-821X(78)90202-9, 1978.

Arai, S.: Characterization of chromian spinel peridotites by olivine - chromian spinel compositional relationships: review and interpretation, Chem. Geol., 113, 191-204, https://doi.org/10.1016/0009-2541(94)90066-3, 1994.

Arai, S. and Miura, M.: Formation and modification of chromitites in the mantle, Lithos, 264, 277-295, https://doi.org/10.1016/j.lithos.2016.08.039, 2016.

Ashworth, J. R.: Two kinds of exsolution in chondritic olivine, Mineral. Mag., 43, 535-538, https://doi.org/10.1180/minmag.1979.043.328.14, 1979.

Ashworth, J. R. and Chambers, A. D.: Symplectic reaction in olivine and the controls of intergrowth spacing in symplectites, J. Petrol., 41, 285-304, https://doi.org/10.1093/petrology/41.2.285, 2000.

Bai, Y., Su, B. X., Chen, C., Yang, S. H., Liang, Z., Xiao, Y., Qin, K. Z., and Malaviarachchi, S. P. K.: Base metal mineral segregation and $\mathrm{Fe}-\mathrm{Mg}$ exchange inducing extreme compositions of olivine and chromite from the Xiadong Alaskan-type complex in the southern part of the Central Asian Orogenic Belt, Ore Geol. Rev., 
90, 184-192, https://doi.org/10.1016/j.oregeorev.2017.01.023, 2017.

Banfield, J. F., Veblen, D. R., and Jones, B. F.: Transmission electron microscopy subsolidus oxidation and weathering of olivine, Contrib. Mineral. Petr., 106, 110-123, https://doi.org/10.1007/BF00306412, 1990.

Bédard, É., Hébert, R., Guilmette, C., Lesage, G., Wang, C., and Dostal, J.: Petrology and geochemistry of the Saga and Sangsang ophiolitic massifs, Yarlung Zangbo Suture Zone, Southern Tibet: Evidence for an arc-back-arc origin, Lithos, 113, 48-67, https://doi.org/10.1016/j.lithos.2009.01.011, 2009.

Bonatti, E. and Michael, P. J.: Mantle peridotites from continental rifts to ocean basins to subduction zones, Earth Planet. Sc. Lett., 91, 297-311, https://doi.org/10.1016/0012821x(89)90005-8, 1989.

Bosi, F., Biagioni, C., and Pasero, M.: Nomenclature and classification of the spinel supergroup, Eur. J. Mineral., 31, 183-192, https://doi.org/10.1127/ejm/2019/0031-2788, 2019.

Brenan, J. M., Neroda, E., Lundstrom, C. C., Shaw, H. F., Ryerson, F. J., and Phinney, D. L.: Behaviour of boron, beryllium and lithium during melting and crystallization constraints from mineral-melt partitioning experiments, Geochim. Cosmochim. Ac., 62, 2129-2141, https://doi.org/10.1016/S00167037(98)00131-8, 1998.

Chan, G. H. N., Aitchison, J. C., Crowley, Q. G., Horstwood, M. S. A., Searle, M. P., Parrish, R. R., and Chan, J. S. L.: U-Pb zircon ages for Yarlung Tsangbo suture zone ophiolites, southwestern Tibet and their tectonic implications, Gondwana Res., 27, 719732, https://doi.org/10.1016/j.gr.2013.06.016, 2015.

Chan, L. H., Leeman, W. P., and You, C. F.: Lithium isotopic composition of Central American Volcanic Arc lavas: implications for modification of subarc mantle by slab-derived fluids, Chem. Geol., 160, 255-280, https://doi.org/10.1016/S00092541(01)00298-4, 1999.

Chan, L. H., Alt, J. C., and Teagle, D. A. H.: Lithium and lithium isotope profiles through the upper oceanic crust: a study of seawater-basalt exchange at ODP sites 504B and 896A, Earth Planet. Sc. Lett., 201, 187-201, https://doi.org/10.1016/s0012821x(02)00707-0, 2002.

Chen, L. H., Zhou, X. H., Chen, S. H., and Zhang, G. H.: Chromite Lamellae in olivine of dunite, Seismology and Geology, 22, 79$86,2000$.

Dai, J. G., Wang, C. S., Polat, A., Santosh, M., Li, Y. L., and Ge, Y. K.: Rapid forearc spreading between 130$120 \mathrm{Ma}$ : evidence from geochronology and geochemistry of the Xigaze ophiolite, southern Tibet, Lithos, 172-173, 1-16, https://doi.org/10.1016/j.lithos.2013.03.011, 2013.

Decitre, S. E., Deloule, E., Reisberg, L., James, R., Agrinier, P., and Mevel, C.: Behavior of $\mathrm{Li}$ and its isotopes during serpentinization of oceanic peridotites, Geochem. Geophy. Geosy., 3, 1, https://doi.org/10.1029/2001GC000178, 2002.

Dick, H. J. B. and Bullen, T.: Chromian chromian spinel as a petrogenetic indicator in abyssal and alpine-type peridotites and spatially associated lavas, Contrib. Mineral. Petr., 86, 54-76, https://doi.org/10.1007/BF00373711, 1984.

Dobrzhinetskaya, L., Green, H. W., and Wang, S.: Alpe Arami: A peridotite massif from depths of more than 300 kilometers, Science, 271, 1841-1845, https://doi.org/10.1126/science.271.5257.1841, 1996.
Drury, M. R. and Van Roermund, H. L. M.: Metasomatic origin for Fe-Ti-rich multiphase inclusions in olivine from kimberlite xenoliths, Geology, 16, 1035-1038, https://doi.org/10.1130/00917613(1988)016<1035:MOFFTR>2.3.CO;2, 1988.

Dubois-Côté, V., Hébert, R., Dupuis, C., Wang, C. S., Li, Y. L., and Dostal, J.: Petrological and geochemical evidence for the origin of the Yarlung Zangbo ophiolites, southern Tibet, Chem. Geol., 214, 265-286, https://doi.org/10.1016/j.chemgeo.2004.10.004, 2005.

Gao, Y. J., Snow, J. E., Casey, J. F., and Yu, J. B.: Coolinginduced fractionation of mantle $\mathrm{Li}$ isotopes from the ultraslowspreading Gakkle Ridge, Earth Planet. Sc. Lett., 301, 231-240, https://doi.org/10.1016/j.epsl.2010.11.003, 2011.

Gong, X. H., Shi, R. D., Griffin, W. L., Huang, Q. S., Xiong, Q., Chen, S. S., Zhang, M., and O'Reilly, S. Y.: Recycling of ancient subduction-modified mantle domains in the Purang ophiolite (southwestern Tibet), Lithos, 262, 11-26, https://doi.org/10.1016/j.lithos.2016.06.025, 2016.

Hacker, B. R., Sharp, T., Zhang, R. Y., Liou, J. G., and Hervig, R. L.: Determining the origin of ultrahigh-pressure lherzolites, Science, 278, 702-704, https://doi.org/10.1126/science.278.5338.702, 1997.

Hamelin, C., Seitz, H. M., Barrat, J. A., Dosso, L., Maury, R., and Chaussidon, M.: A low $\delta^{7} \mathrm{Li}$ lower crustal component: evidence from an alkalic intraplate volcanic series (Chaîne des Puys, French Massif Central), Chem. Geol., 266, 205-217, https://doi.org/10.1016/j.chemgeo.2009.06.005, 2009.

Hébert, R., Adamson, A. C., and Komor, S. C.: Metamorphic petrology of ODP 109, Hole 670A serpentinized peridotites: serpentinization processes at a slow spreading ridge environment, in: Proceedings of the ODP, Sci. Results 106/109, edited by: Detrick, R., Honnorez, J., Bryan, W. B., and Juteau, T., College Station, Texas, 103-115, 1990.

Hébert, R., Huot, F., Wang, C. S., and Liu, Z.: Yarlung Zangbo ophiolites (southern Tibet) revisited: geodynamic implication from the mineral record, in: Ophiolites in Earth History, edited by: Dilek, Y. and Robinson, P. T., Geological Society London Special Publications, 165-190, https://doi.org/10.1144/GSL.SP.2003.218.01.10, 2003.

Hellebrand, E., Snow, J. E., Dick, H. J. B., and Hofmann, A. W.: Coupled major and trace elements as indicators of the extent of melting in mid-ocean-ridge peridotites, Nature, 410, 677-681, https://doi.org/10.1038/35070546, 2001.

Ishii, T., Robinson, P. T., Maekawa, H., and Fiske, R.: Petrological studies of peridotites from diapiric serpentinite seamounts in the Izu-Ogasawara-Mariana Forearc, Leg 125, in: Proceedings of the Ocean Drilling Program, Scientific Results, 125, Ocean Drilling Program, edited by: Fryer, O., Pearce, J. A., and Stokking, L. B., College Station, TX, 445-485, 1992.

Ishikawa, T., Fujisawa, S., Nagaishi, K., and Masuda, T.: Trace element characteristics of the fluid liberated from amphibolitefacies slab: Inference from the metamorphic sole beneath the Oman ophiolite and implication for boninite genesis, Earth Planet. Sc. Lett., 240, 355-377, https://doi.org/10.1016/j.eps1.2005.09.049, 2005.

Johnson, K. T. M., Dick, H. J. B., and Shimizu, N.: Melting in the oceanic upper mantle: an ion microprobe study of diopsides in abyssal peridotites, J. Geophys. Res., 95, 2661-2678, https://doi.org/10.1029/JB095iB03p02661, 1990. 
Kamenetsky, V. S., Crawford, A. J., and Meffre, S.: Factors controlling the chemistry of magmatic spinel: an empirical study of associated olivine, Cr-spinel and melt inclusions from primitive rocks, J. Petrol., 42, 655-671, https://doi.org/10.1093/petrology/42.4.655, 2001.

Kelemen, P. B., Johnson, K. T. M., Kinzler, R. J., and Irving, A. J.: High-field-strength element depletions in arc basalts due to mantle magma interaction, Nature, 345, 521-524, https://doi.org/10.1038/345521a0, 1990.

Li, J. F., Xia, B., Liu, L. W., Xu, L. F., He, G. S., Wang, H., Zhang, Y. Q., and Yang, Z. Q.: SHRIMP U-Pb zircon dating of diabase in the Langa Co ophiolite, Purang, Tibet, China, and its geological significance, Geological Bulletin of China, 27, 1739-1743, 2008 (in Chinese).

Li, X. P., Chen, H. K., Wang, Z. L., Wang, L. J., Yang, J. S., and Robinson, P. T.: Spinel peridotite, olivine websterite and the textural evolution of the Purang ophiolite complex, western Tibet, J. Asian Earth Sci., 110, 55-71, https://doi.org/10.1016/j.jseaes.2014.06.023, 2015.

Liang, F. H., Yang, J. S., Xu, Z. Q., and Zhao, J. N.: Chromium in the olivine lattice: Chromium -rich olivines and their implication of deep mantle origin in the Luobusa mantle peridotite and chromitite, Tibet, Acta Petrol. Sin., 30, 2125-2136, 2014 (in Chinese with English abstract).

Liang, Z., Xiao, Y., Thakurta, J., Su, B. X., Chen, C., Bai., Y., and Sakyi, P. A.: Exsolution lamellae in olivine grains of dunite units from different types of mafic-ultramafic complexes, Acta Geological Sinica, 92, 586-599, 2018.

Libourel, G.: Systematics of calcium partitioning between olivine and silicate melt: imphcations for melt Structure ad calcium content of magmatic olivines, Contrib. Mineral. Petr., 136, 60-80, https://doi.org/10.1007/s004100050524, 1999.

Liu, C. Z., Wu, F. Y., Wilde, S. A., Yu, L., and Li, J.: Anorthitic plagioclase and pargasitic amphibole in mantle peridotites from the Yungbwa ophiolite (southwestern Tibetan Plateau) formed by hydrous melt metasomatism, Lithos, 114, 413-422, https://doi.org/10.1016/j.lithos.2009.10.008, 2010.

Liu, C. Z., Zhang, C., Yang, L., Zhang, L., Ji, W. Q., and Wu, F. Y.: Formation of gabbronorites in the Purang ophiolite (SW Tibet) through melting of hydrothermally altered mantle along a detachment fault, Lithos, 205, 127-141, https://doi.org/10.1016/j.lithos.2014.06.019, 2014.

Liu, F., Yang, J. S., Lian, D. Y., Zhao, H., Zhao, Y. J., and Zhang, L.: The Genesis and Tectonic Significance of Mafic Dikes in the Western Part of the Yarlung Zangbo Suture Zone, Tibet, Acta Geoscientia Sinica, 36, 441-454, 2015.

Liu, Z., Li, Y., Xiong, F. H., Wu, D., and Liu, F.: Petrology and geochronology of MOR gabbro in the Purang ophiolite of western Tibet, China, Acta Petrol. Sin., 27, 3169-3279, 2011.

Lundstrom, C. C., Chaussidon, M., Hsui, A. T., Kelemen, P., and Zimmerman, M.: Observations of Li isotopic variations in the Trinity Ophiolite: evidence for isotopic fractionation by diffusion during mantle melting, Geochim. Cosmochim. Ac., 69, 735-751, https://doi.org/10.1016/j.gca.2004.08.004, 2005.

Malpas, J., Zhou, M., Robinson, P. T., and Reynolds, P. H.: Geochemical and geochronological constraints on the origin and emplacement of the Yarlung Zangbo ophiolites, Southern Tibet, in: Ophiolites Through Earth History, edited by: Dilek, Y. and Robinson, P. T., Geolog- ical Society, London, Special Publications, 218, 191-206, https://doi.org/10.1144/GSL.SP.2003.218.01.11, 2003.

Markl, G., Marks, M., and Wirth, R.: The influence of T, $\mathrm{aSiO}_{2}$ and $\mathrm{fO}_{2}$ on exsolution textures in Fe-Mg olivine: An example from augite syenites of the Ilimaussaq Intrusion, South Greenland, Am. Mineral., 86, 36-46, https://doi.org/10.2138/am-20010105, 2001.

Marks, M. A. W., Rudnick, R. L., McCammon, C., Vennemann, T., and Markl, G.: Arrested kinetic Li isotope fractionation at the margin of the Ilímaussaq complex, South Greenland: evidence for open-system processes during final cooling of peralkaline igneous rocks, Chem. Geol., 246, 207-230, https://doi.org/10.1016/j.chemgeo.2007.10.001, 2007.

Marschall, H. R., Pogge von Strandmann, P. A. E., Seitz, H. M., Elliott, T., and Niu, Y. L.: The lithium isotopic composition of orogenic ec ogites and deep subducted slabs, Earth Planet. Sc. Lett., 262, 563-580, https://doi.org/10.1016/j.eps1.2007.08.005, 2007.

Meng, Y. K., Xu, Z. Q., Santosh, M., Ma, X. X., Chen, X. J., Guo, G. L., and Liu, F.: Late Triassic crustal growth in southern Tibet: Evidence from the Gangdese magmatic belt, Gondwana Res., 37, 449-464, https://doi.org/10.1016/j.gr.2015.10.007, 2016.

Meng, Y. K., Xiong, F. H., Yang, J. S., Liu, Z., Kieran, A., Robinson, P. T., and $\mathrm{Xu}, \mathrm{X}$. Z.: Geochronology and geochemistry of the Magmatic Rocks from the Zedong Ophiolite in the Eastern Yarlung-Zangbo Suture zone, Southern Tibet, J. Earth Sci., 30, 1125-1143, https://doi.org/10.1007/s12583-019-1248-3, 2019.

Miller, C., Thöni, M., Frank, W., Schuster, R., Melcher, F., Meisel, T., and Zanetti, A.: Geochemistry of tectonomagmatic affinity of the Yungbwa ophiolite, SW Tibet, Lithos, 66, 155-172, https://doi.org/10.1016/S0024-4937(02)00217-7, 2003.

Mikouchi, T., Yamada, I., and Miyamoto, M.: Spplectic exsolution in olivine from the Nakhla martian meteorite, Meteoritics and Planetary Science, 35, 937-942, https://doi.org/10.1111/j.19455100.2000.tb01483.x, 2000.

Miyawaki, R., Hatert, F., Pasero, M., and Mills, S. J.: IMA Commission on New Minerals, Nomenclature and Classification (CNMNC) - Newsletter 52, Eur. J. Mineral., 32, 1-11, https://doi.org/10.5194/ejm-32-1-2020, 2020.

Moseley, D.: Ilmenite exsolution in olivine, Am. Mineralo., 66, 976-979, 1981.

Moseley, D.: Symplectic exsolution in olivine, Am. Mineral., 69, 139-153, 1984.

Otten, M. T.: The subsolidus history of the Artfjället Gabbro: a TEM study ofolivine, augite and orhopyroxene, J. Petrol., 26, 488-514, https://doi.org/10.1093/petrology/26.2.488, 1985.

Ozawa, K.: Melting and melt segregation in the mantle wedge above a subduction zone: evidence from the chromite-bearing peridotites of the Miyamori ophiolite complex, northeastern Japan, J. Petrol., 35, 647-678, https://doi.org/10.1093/petrology/35.3.647, 1994.

Pagé, P., Bédard, J. H., Schroetter, J. M., and Tremblay, A.: Mantle petrology and mineralogy of the Thetford mines ophiolite complex, Lithos, 100, 255-292, https://doi.org/10.1016/j.lithos.2007.06.017, 2008.

Parkinson, I. J. and Pearce, J. A.: Peridotites from the Izu-Bonin-Mariana forearc (ODP Leg 125): evidence for mantle melting and melt-mantle interaction in a 
supra-subduction zone setting, J. Petrol., 39, 1577-1618, https://doi.org/10.1093/petroj/39.9.1577, 1998.

Parkinson, I. J., Arculus, R. J., and Eggins, S. M.: Peridotite xenoliths from Grenada, Lesser Antilles island arc, Contrib. Mineral. Petr., 146, 241-262, https://doi.org/10.1007/s00410-003-0500-z, 2003.

Pearce, J. A., Barker, P. F., Edwards, S. J., Parkinson, I. J., and Leat, P. T.: Geochemistry and tectonic significance of peridotites from the South Sandwich arc-basin system, South Atlantic, Contrib. Mineral. Petr., 139, 36-53, https://doi.org/10.1007/s004100050572, 2000.

Python, M., Ishida, Y., Ceuleneer, G., and Arai, S.: Trace element heterogeneity in hydrothermal diopside: evidence for $\mathrm{Ti}$ depletion and Sr-Eu-LREE enrichment during hydrothermal metamorphism of mantle harzburgite, J. Mineral. Petrol. Sci., 102, 143149, https://doi.org/10.2465/jmps.060830, 2007

Ren, Y. F., Chen, F. Y., and Yang, J. S.: Exsolutions of diopside and magnetite in olivine from mantle dunite, Luobusa ophiolite, Tibet, China, Acta Geologica Sinica-English Edition, 82, 377384, 2008.

Richter, F., Watson, B., Chaussidon, M., Mendybaev, R., and Ruscitto, D.: Lithium isotope fractionation by diffusion in minerals. Part 1: pyroxenes, Geochim. Cosmochim. Ac., 126, 352-370, https://doi.org/10.1016/j.gca.2013.11.008, 2014.

Risold, A. C., Trommsdorff, V., Reusser, E., and Ulmer, P.: Genesis of $\mathrm{FeTiO}_{3}$ inclusions in garnet peridotites from the Central Alps, Terra Nova, 9, 28-29, 1997.

Sakae, S. and Jun-Ichi, K.: Clinopyroxene REE geochemistry of the Red Hills peridotite, New Zealand: Interpretation of magmatic processes in the upper mantle and the Moho transition zone, J. Petrol., 48, 119-139, https://doi.org/10.1093/petrology/eg1056, 2007.

Savov, I. P., Ryan, J. G., D’Antonio, M., and Fryer, P.: Shallow slab fluid release across and along with the Mariana arc-basin system: insights from the geochemistry of serpentinized peridotites from the Mariana forearc, J. Geophys. Res.-Sol. Ea., 112, B09205, https://doi.org/10.1029/2006JB004749, 2007.

Song, S. G., Zhang, L. F., and Niu, Y. L.: Ultra-deep origin of garnet peridotite from the North Qaidam ultrahigh-pressure belt, northern Tibetan Plateau, NW China, Am. Mineral., 9, 1330-1336, https://doi.org/10.2138/am-2004-8-922, 2004.

Su, B. X., Gu, X. Y., Deloule, E., Zhang, H. F., Li, Q. L., Li, X. H., Vigier, N., Tang, Y. J., Tang, G. Q., Liu, Y., Brewer, A., Mao, Q., and Ma, Y. G.: Potential orthopyroxene, clinopyroxene and olivine reference materials for in situ lithium isotope determination, Geostand. Geoanal. Res., 39, 357-369, https://doi.org/10.1111/j.1751-908X.2014.00313.x, 2015.

Su, B. X., Zhou, M. F., and Robinson, P. T.: Extremely large fractionation of $\mathrm{Li}$ isotopes in a chromite-bearing mantle sequence, Sci. Rep., 6, 22370, https://doi.org/10.1038/srep22370, 2016.

Su, B. X., Chen, C., Bai, Y., Pang, K. N., Qin, K. Z., and Sakyi, P. A.: Lithium isotopic composition of Alaskantype intrusion and its implication, Lithos, 286-287, 363-368, https://doi.org/10.1016/j.lithos.2017.06.024, 2017.

Su, B. X., Chen, C., Pang, K. N., Sakyi, P. A., Uysal, İ., Avc1, E., Liu, X., and Zhang, P. F.: Melt penetration in the oceanic lithosphere: $\mathrm{Li}$ isotope records from the Pozant1Karsantiophiolite in southern Turkey, J. Petrol., 59, 191-205, https://doi.org/10.1093/petrology/egy023, 2018.
Su, B. X., Zhou, M. F., Jing, J. J., Robinson, P. T., Chen, C., Xiao, Y., Liu, X., Shi, R. D., Lenaz, D., and Hu, Y.: Distinctive melt activity and chromite mineralization in Luobusa and Purang ophiolites, southern Tibet: constraints from trace element compositions of chromite and olivine, Sci. Bull., 64, 108-121, https://doi.org/10.1016/j.scib.2018.12.018, 2019.

Teng, F. Z., McDonough, W. F., Rudnick, R. L., Dalpé, C., Tomascak, P. B., Chappell, B. W., and Gao, S.: Lithium isotopic composition and concentration of the upper continental crust, Geochim. Cosmochim. Ac., 68, 4167-4178, https://doi.org/10.1016/j.gca.2004.03.031, 2004.

Teng, F. Z., Dauphas, N., Helz, R. T., Gao, S., and Huang, S.: Diffusion-driven magnesium and iron isotope fractionation in Hawaiian olivine, Earth Planet. Sc. Lett., 308, 317-324, https://doi.org/10.1016/j.epsl.2011.06.003, 2011.

Tomascak, P. B., Widom, E., Benton, L. D., Goldstein, S. L., and Ryan, J. G.: The control of lithium budgets in island arcs, Earth Planet. Sc. Lett., 196, 227-238, https://doi.org/10.1016/s0012821x(01)00614-8, 2002.

Tomascak, P. B., Magna, T., and Dohmen, R.: Advances in Lithium Isotope Geochemistry, Springer International Publishing Switzerland, 1-195, https://doi.org/10.1007/978-3-319-01430-2, 2016.

Vils, F., Pelletier, L., Kalt, A., Müntener, O., and Ludwig, T.: The lithium, boron and beryllium content of serpentinized peridotites from ODP Leg 209 (Sites 1272A and 1274A): implications for lithium and boron budgets of oceanic lithosphere, Geochim. Cosmochim. Ac., 72, 5475-5504, https://doi.org/10.1016/j.gca.2008.08.005, 2008.

Weyer, S. and Seitz, H. M.: Coupled lithium- and iron isotope fractionation during magmatic differentiation, Chem. Geol., 294295, 42-50, https://doi.org/10.1016/j.chemgeo.2011.11.020, 2012.

Wimpenny, J., Gislason, S. R., James, R. H., Gannoun, A., Pogge von Strandmann, P. A. E., and Burton, K.: The behaviour of $\mathrm{Li}$ and $\mathrm{Mg}$ isotopes during primary phase dissolution and secondary mineral formation in basalt, Geochim. Cosmochim. Ac., 74, 5259-5279, https://doi.org/10.1016/j.gca.2010.06.028, 2010.

Wirth, R.: Focused ion beam (FIB) combined with SEM and TEM: advanced analytical tools for studies of chemical composition, microstructure and crystal structure in geomaterials on a nanometre scale, Chem. Geol., 261, 217-229, https://doi.org/10.1016/j.chemgeo.2008.05.019, 2009.

Wunder, B., Meixner, A., Romer, R. L., and Heinrich, W.: Temperature-dependent isotopic fractionation of lithium between clinopyroxene and high-pressure hydrous fluids, Contrib. Mineral. Petr., 151, 112-120, https://doi.org/10.1007/s00410005-0049-0, 2006.

Wunder, B., Deschamps, F., Watenphul, A., Guillot, S., Meixner, A., Romer, R. L., and Wirth, R.: The effect of chrysotile nano-tubes on the serpentine-fluid Li-isotopic fractionation, Contrib. Mineral. Petr., 159, 781-790, https://doi.org/10.1007/s00410-0090454-X, 2010.

Xiao, Y., Teng, F. Z., Su, B. X., Hu, Y., Zhou, M. F., Zhu, B., Shi, R. D., Huang, Q. S., Gong, X. H., and He, Y. S.: Iron and magnesium isotopic constraints on the origin of chemical heterogeneity in podiform chromitite from the Luobusa ophiolite, Tibet, Geochem. Geophy. Geosy., 17, 940-953, https://doi.org/10.1002/2015gc006223, 2016. 
Xiao, Y., Zhang, H. F., Su, B. X., Zhu, B., Chen, B., Chen, C., and Sakyi, P. A.: Partial melting control of lithium concentrations and isotopes in the Cenozoic lithospheric mantle beneath Jiande area, the Cathaysia block of SE China, Chem. Geol., 466, 750-761, https://doi.org/10.1016/j.chemgeo.2017.07.024, 2017.

Xiong, F. H., Yang, J. S., Liu, Z., Guo, G., L., Chen, S. Y., Xu, X. Z., Li, Y., and Liu, F.: High-Cr and high-Al chromitite found in western Yarlung-Zangbo suture zone in Tibet, Acta Petrol. Sin., 29, 1878-1908, 2013 (in Chinese with English abstract).

Xiong, F. H., Yang, J. S., Robinson, P. T., Xu, X. Z., Liu, Z., Li, Y., Li, J. Y., and Chen, S. Y.: Origin of podiform chromitite, a new model based on the Luobusa ophiolite, Tibet, Gondwana Res., 27, 525-542, https://doi.org/10.1016/j.gr.2014.04.008, 2015.

Xiong, F. H., Yang, J. S., Guo, G. L., Liu, Z., Xu, X. Z., Tian, Y. Z., Lai, S. M., Chen, Y. H., and Zhang, L.: Exsolution in Olivine from the Lower Cr\# Dunite in the Purang Ophiolite, the Western portion of the Yarlung-Zangbo Suture Zone in Tibet, Acta Geoscientica Sinica, 37, 79-89, 2016 (in Chinese with English abstract).

Xiong, F. H., Yang, J. S., Dilek, Y., and Wang, C. L.: Nanoscale Diopside and Spinel Exsolution in Olivine from Dunite of the Tethyan Ophiolites, Southwestern Turkey: Implications for the multi-stage process, J. Nanosci. Nanotechno., 17, 6587-6596, https://doi.org/10.1166/jnn.2017.14506, 2017.

Xiong, F. H., Yang, J. S., Xu, X. Z., Kapsiotis, A., Hao, X. L., and Liu, Z.: Compositional and isotopic heterogeneities in the Neo-Tethyan upper mantle recorded by coexisting Alrich and Cr-rich chromitites in the Purang peridotite massif, SW Tibet (China), J. Asian Earth Sci., 159, 109-129, https://doi.org/10.1016/j.jseaes.2018.03.024, 2018.

Xiong, F. H., Meng, Y. K., Yang, J. S., Liu, Z., Xu, X. Z., Eslami, A., and Zhang, R.: Geochronology and petrogenesis of the mafic dykes from the Purang ophiolite: Implications for the evolution of the western Yarlung-Tsangpo suture zone, southwestern Tibet, Geosci. Front., 11, 277-292, https://doi.org/10.1016/j.gsf.2019.05.006, 2019a.

Xiong, F. H., Liu, Z., Kapsiotis, A., Yang, J. S., Lenaz, D., and Robinson, P. T.: Petrogenesis of lherzolites from the Purang ophiolite, Yarlung-Zangbo Suture Zone, Tibet: origin and significance of ultra-high pressure and other "unusual" minerals in the Neo-Tethyan lithospheric mantle, Int. Geol. Rev., 17,2184-2210, https://doi.org/10.1080/00206814.2019.1584771, 2019b.

Xiong, F. H., Dilek, Y., Xu, X. Z., and Yang, J. S.: Opx-Cpx exsolution textures in lherzolites of the Cretaceous Purang Ophiolite (S. Tibet, China), and the deep mantle origin of Neotethyan abyssal peridotites, Int. Geol. Rev., https://doi.org/10.1080/00206814.2019.1627678, in press, 2019c.

Xu, X. Z., Yang, J. S., Guo, G. L., and Li, J. Y.: Lithological research on the Purang mantle peridotite in western Yarlung-Zangbo suture zone in Tibet, Acta Petrol. Sin., 27, 3179-3196, 2011 (in Chinese with English abstract).
Yamaji, K., Makita, Y., Watanabe, H., Sonoda, A., Kanoh, H., Hirotsu, T., and Ooi, K.: Theoretical estimation of lithium isotopic reduced partition function ratio for lithium ions in aqueous solution, Journal of Physical and Chemical Annual, 105, 602-613, https://doi.org/10.1021/jp001303i, 2001.

Yang, J. S., Xu, X. Z., Li, Y., Li, J. Y., Ba, D. Z., Rong, H., and Zhang, Z. M.: Diamonds recovered from peridotite of the Purang ophiolite in the Yarlung-Zangbo suture of Tibet: A proposal for a new of diamond occurrence, Acta Petrol. Sin., 27, 3171-3178, 2011 (in Chinese with English abstract).

Zhang, P. F., Zhou, M. F., Robinson, P. T., Pearce, J. A., Malpas, J., Liu, Q. Y., and Xia, X. P.: Evolution of nascent mantle wedges during subduction initiation: $\mathrm{Li}-\mathrm{O}$ isotopic evidence from the $\mathrm{Lu}-$ obusa ophiolite, Tibet, Geochim. Cosmochim. Ac., 245, 35-58, https://doi.org/10.1016/j.gca.2018.09.037, 2019a.

Zhang, P. F., Zhou, M. F., Liu, Q. Y., Malpas, J., Robinson, P. T., and He, Y. S.: Modification of mantle rocks by plastic flow below spreading centers: Fe isotopic and fabric evidence from the Luobusa ophiolite, Tibet, Geochim. Cosmochim. Ac., 253, 84110, https://doi.org/10.1016/j.gca.2019.03.008, 2019b.

Zhang, R. Y., Shu, J. F., Mao, H. K., Juhn, G., and Liou, J. G.: Magnetite lamellae in olivine and clinohumite from Dabie UHP ultramafic rock, central China, Am. Mineral., 84, 564-569, 1999.

Zhang, R. Y., Liou, J. G., Yang, J. S., Liu, L., and Borming, J.: Garnet peridotites in UHP mountain belts of China, Int. Geol. Rev., 46, 981-1004, https://doi.org/10.2747/00206814.46.11.981, 2004.

Zhao, W. X., Hu, Y. X., Li, X. M., Liao, C. Z., Du, J. J., and Jiang, D.: The compositional in the homogeneity of the needle-exsolution magnetites in olivine from Bixiling garnet peridotite, Acta Petrologica et Mineralogica, 25, 40-44, https://doi.org/10.1016/S1872-2040(06)60043-1, 2006.

Zheng, H., Huang, Q. T., Kapsiotis, A., Lenaz, D., Velicogna, M., Xu, C., Cheng, C., Xia, B., Liu, W. L., Xiao, Y., and Yang, J.: Coexistence of MORB- and OIB-like dolerite intrusions in the Purang ultramafic massif, SW Tibet: A paradigm of plumeinfluenced MOR-type magmatism prior to subduction initiation in the Neo-Tethyan lithospheric mantle, Geol. Soc. Am. Bull., 131, 1276-1294, https://doi.org/10.1130/B35005.1, 2019.

Zhou, M. F., Robinson, P. T., Malpas, J., and Li, Z.: Podiform chromitites in the Luobusa ophiolite (southern Tibet): Implications for melt-rock interaction and chromite segregation in the upper mantle, J. Petrol., 37, 3-21, https://doi.org/10.1093/petrology/37.1.3, 1996.

Zhou, M. F., Robinson, P. T., Malpas, J., Edwards, S. J., and Qi, L.: REE and PGE geochemical constraints on the formation of dunites in the Luobusa ophiolite, southern Tibet, J. Petrol., 46, 615-639, https://doi.org/10.1093/petrology/egh091, 2005. 